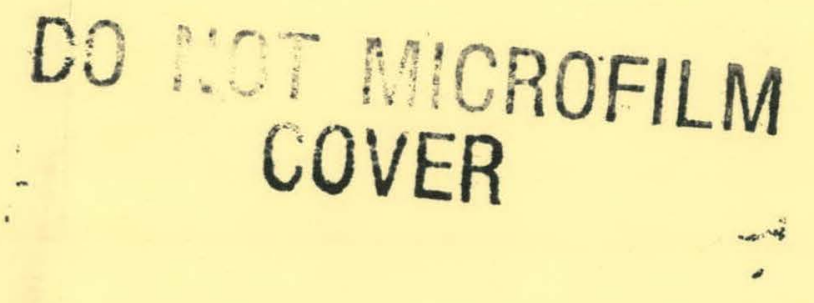

\title{
Agriculture-Related Radiation Dose Calculations
}

\author{
Technical Report
}

October 1987

Jeffrey M. Furr

James J. Mayberry

David A. Waite

Office of Nuclear Waste Isolation

Battelle Memorial Institute

1303 West First Street

Hereford, Texas 79045-4208

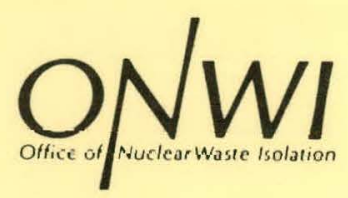

BATTELLE Project Management Division 


\section{DISCLAIMER}

This report was prepared as an account of work sponsored by an agency of the United States Government. Neither the United States Government nor any agency Thereof, nor any of their employees, makes any warranty, express or implied, or assumes any legal liability or responsibility for the accuracy, completeness, or usefulness of any information, apparatus, product, or process disclosed, or represents that its use would not infringe privately owned rights. Reference herein to any specific commercial product, process, or service by trade name, trademark, manufacturer, or otherwise does not necessarily constitute or imply its endorsement, recommendation, or favoring by the United States Government or any agency thereof. The views and opinions of authors expressed herein do not necessarily state or reflect those of the United States Government or any agency thereof. 


\section{DISCLAIMER}

Portions of this document may be illegible in electronic image products. Images are produced from the best available original document. 


\section{BIBLIOGRAPHIC DATA}

Furr, Jeffrey M., James J. Mayberry, and David A. Waite, 1987. Agriculture-Related Radiation Dose Calculations, BMI/ONWI-669, Office of Nuclear Waste Isolation, Battelle Memorial Institute, Hereford, TX.

\section{NOTICE}

This report was prepared as an account of work sponsored by an agency of the United States Government. Neither the United States Government nor any agency thereof, nor any of their employees, makes any warranty, expressed or implied, or assumes any legal liability or responsibility for the accuracy, completeness, or usefulness of any information, apparatus, product, or process disclosed, or represents that its use would not infringe privately owned rights. Reference herein to any specific commercial product, process, or service by trade name, trademark, manufacturer, or otherwise, does not necessarily constitute or imply its endorsement, recommendation, or favoring by the United States Government or any agency thereof. The views and opinions of authors expressed herein do not necessarily state or reflect those of the United States Government or any agency thereof.

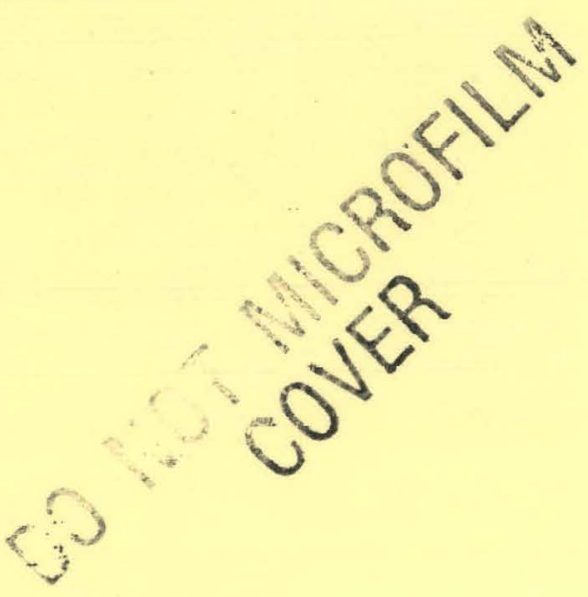

Printed in the United States of America Available from

National Technical Information Service U.S. Department of Commerce 5285 Port Royal Road Springfield, VA 22161

NTIS price codes Printed copy: A04 Microfiche copy: A01 
BMI/ONWI-669

Distribution Category UC-70

BMI/ONWI -669

DE88 004645

\section{Agriculture-Related Radiation Dose Calculations}

Technical Report

October 1987

Jeffrey M. Furr

James J. Mayberry

David A. Waite

Office of Nuclear Waste Isolation

Battelle Memorial Institute

1303 West First Street

Hereford, Texas 79045-4208

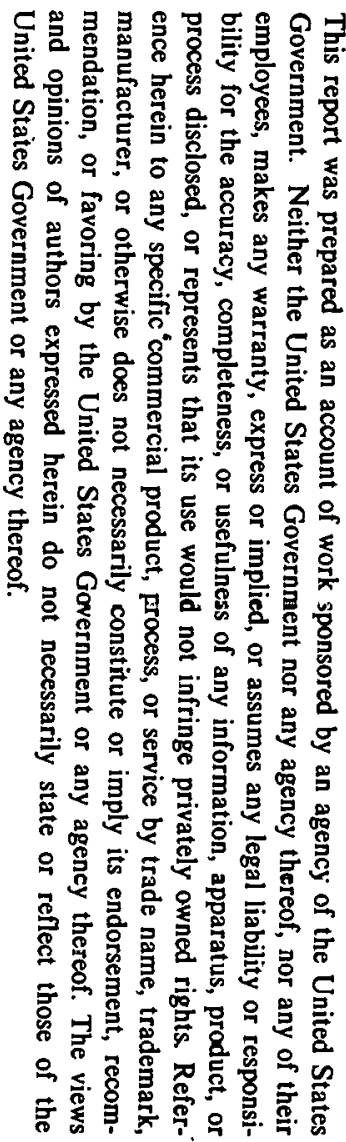

The content of this report was effective as of December 1986. This report was prepared by Batte ect Management Division, Office of Nuclear Waste Isolation, under Contract No. DE-AC02-83 with the U.S. Department of Energy. 
THIS PAGE

\section{WAS INTENTIONALLY LEFT BLANK}


Estimates of radiation dose to the public must be made at each stage in the identification and qualification process leading to siting a high-level nuclear waste repository. Specifically considering the ingestion pathway, this paper examines questions of reliability and adequacy of dose calculations in relation to five stages of data availability (geologic province, region, area, location, and mass balance) and three methods of calculation (population, population/food production, and food production driven). Calculations were done using the model PABLM with data for the Permian and Palo Duro Basins and the Deaf Smith County area. Conclusions drawn are that the extra effort expended in gathering agricultural data at succeeding environmental characterization levels does not appear justified, since dose estimates do not differ greatly; that effort would be better spent determining usage of food types that contribute most to the total dose; and that consumption rate and the air dispersion factor are critical to assessment of radiation dose via the ingestion pathway. 
THIS PAGE

\section{WAS INTENTIONALLY \\ LEFT BLANK}


The National Waste Terminal Storage Program was established in 1976 by the U.S. Department of Energy's predecessor, the Energy Research and Development Administration. In September 1983, this program became the Civilian Radioactive Waste Management (CRWM) Program. Its purpose is to develop technology and provide facilities for safe, environmentally acceptable, permanent disposal of high-level waste (HLW). HLW includes wastes from both commercial and defense sources, such as spent (used) fuel from nuclear power reactors, accumulations of wastes from production of nuclear weapons, and solidified wastes from fuel reprocessing.

The information in this report pertains to the radiological studies of the Salt Repository Project of the Office of Geologic Repositories in the CRWM Program. 
THIS PAGE

WAS INTENTIONALLY

LEFT BLANK 


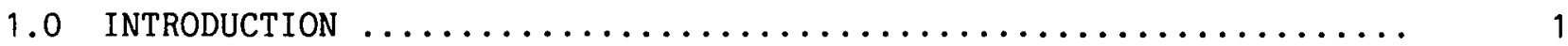

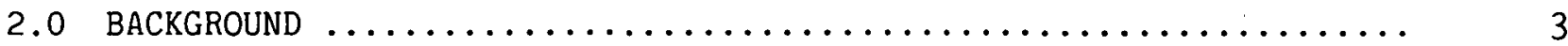

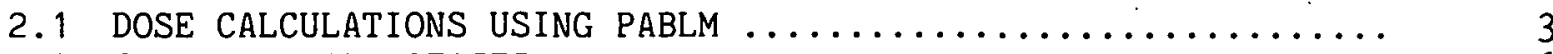

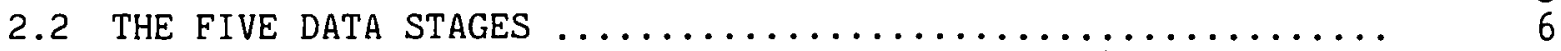

3.0 METHODS $\ldots \ldots \ldots \ldots \ldots \ldots \ldots \ldots \ldots \ldots \ldots \ldots \ldots \ldots \ldots \ldots \ldots \ldots \ldots \ldots \ldots \ldots$

3.1 METHOD A: POPULATION-DRIVEN ASSESSMENT ............. 7

3.2 METHOD B: POPULATION/FOOD PRODUCTION-DRIVEN ASSESSMEN II ....

3.3 METHOD $C:$ FOOD PRODUCTION-DRIVEN ASSESSMENT $\ldots \ldots \ldots \ldots \ldots \ldots$.

4.0 DATA BASES FOR THE FIVE STAGES $\ldots \ldots \ldots \ldots \ldots \ldots \ldots \ldots \ldots \ldots \ldots \ldots \ldots$

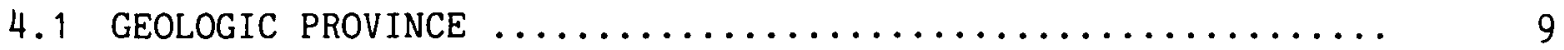

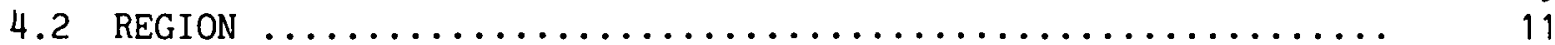

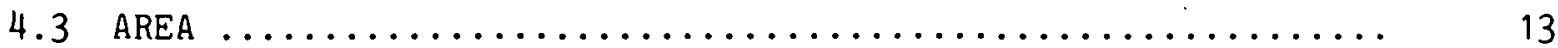

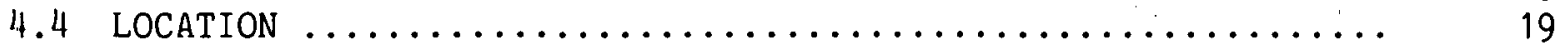

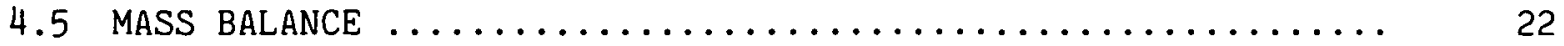

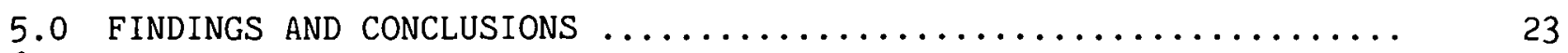

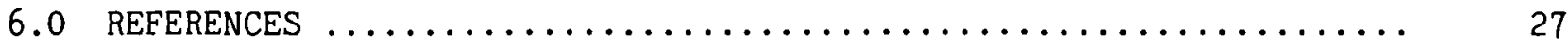

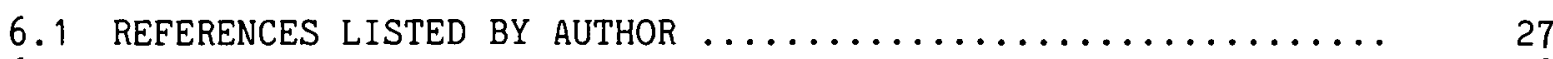

6.2 FEDERAL REGULATIONS AND STATUTES $\ldots \ldots \ldots \ldots \ldots \ldots \ldots \ldots \ldots \ldots \ldots$

APPENDIX A. SENSITIVITY ANALYSIS OF PABLM INPUT PARAMETERS ......... 29

APPENDIX B. VALUES FOR DOSE CALCULATIONS $\ldots \ldots \ldots \ldots \ldots \ldots \ldots \ldots \ldots \ldots \ldots . . \ldots$

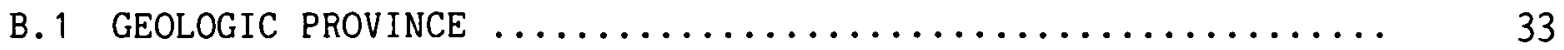

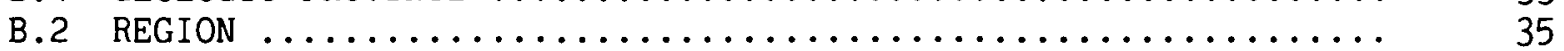

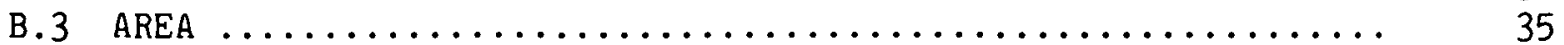

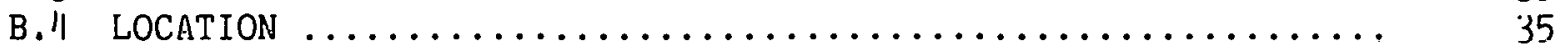




\section{LIST OF FIGURES}

Figure

Title

Page

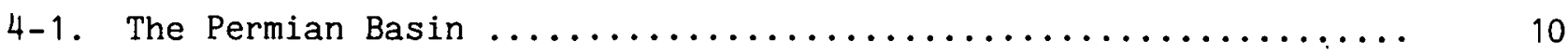

A-1. I-129 Dose Versus Consumption ..................... 31

A-2. I-129 Dose Versus Translocation $\ldots \ldots \ldots \ldots \ldots \ldots \ldots \ldots \ldots \ldots \ldots \ldots$

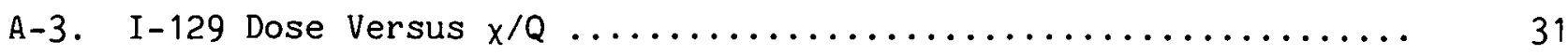

A-4, T-129 Dose Versus Holdup $\ldots \ldots \ldots \ldots \ldots \ldots \ldots \ldots \ldots \ldots \ldots \ldots \ldots \ldots \ldots . . \ldots \ldots$

A-5. In 129 Dnse Versus Growing Period $\ldots \ldots \ldots \ldots \ldots \ldots \ldots \ldots \ldots \ldots \ldots \ldots \ldots \ldots$

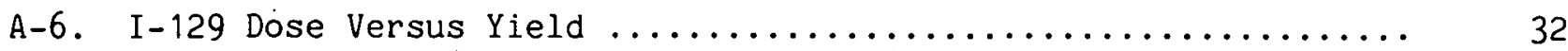

A-7. I-129 Dose Minus Minimum Value Versus Yield ............. 32

B-1. PABLM Sample Output $\ldots \ldots \ldots \ldots \ldots \ldots \ldots \ldots \ldots \ldots \ldots \ldots \ldots \ldots \ldots \ldots \ldots$ 


\section{LIST OF TABLES}

$\underline{\text { Table }}$

Title

Page

4-1. States' Top Four Agricultural Commodities ............... 11

4-2. Recommended Values for Consumption for the Average Individual in Lieu of Site-Specific Data ...................... 12

4-3. Agricultural Information for the Geologic Province .......... 12

4-4. Permian Basin State Weighting Factors .................. 14

4-5. Agricultural Information for the Region $\ldots \ldots \ldots \ldots \ldots \ldots \ldots \ldots \ldots$

4-6. Annual Atmospheric Stability Classes for Amarillo

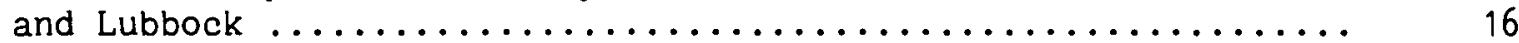

4-7. Population and Areal Relationships of the Palo Duro Basin and

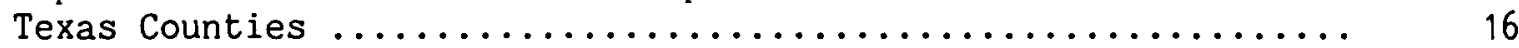

4-8. Populations for Counties Near the Palo Duro Basin ......... 17

4-9. Recommended Values for Consumption Rates for the Average Individual in Lieu of Site-Specific Data ............... 17

4-10. Agricultural Information for the Area ................. 18

4-11. Deaf Smith County Location Consumption Rates .............. 20

4-12. Agricultural Information for the Location $\ldots \ldots \ldots \ldots \ldots \ldots \ldots \ldots$

5-1. Maximum Individual Dose and Total Population by Method ....... 24

B-1. Operational Repository Emission $\ldots \ldots \ldots \ldots \ldots \ldots \ldots \ldots \ldots \ldots \ldots$

B-2. Ingestion Pathways Input Data, Province $\ldots \ldots \ldots \ldots \ldots \ldots \ldots \ldots \ldots$

B-3. Affected Population by Agricultural Good, Province ......... 36

B-4. Individual Dose by Agricultural Good, Province ........... 37

B-5. Population Dose by Method and Agricultural Good, Province ..... 37

B-6. Ingestion Pathways Input Data, Region $\ldots \ldots \ldots \ldots \ldots \ldots \ldots \ldots \ldots$

B-7. Affected Population by Agricultural Good, Region ........... 38

B-8. Individual Dose by Agricultural Good, Region ............. 39

B-9. Population Dose by Method and Agricultural Good, Region ....... 39 
LIST OF TABLES

(Continued)

Table

Title

Page

B-10. Ingestion Pathways Input Data, Area ................. 40

B-11. Affected Population by Agricultural Good, Area ........... 41

B-12. Individual Dóse by Agricultural Good, Area $\ldots \ldots \ldots \ldots \ldots \ldots \ldots$

B-13. Population Annual Dose by Method and Agricultural Good,

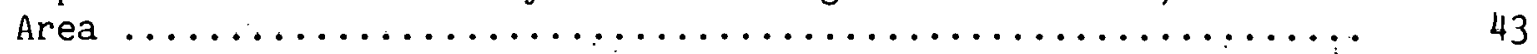

B-14. Population 50-Year Dose by Method and Agricultural Good,

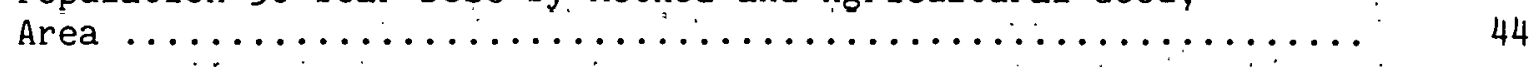

B-15. Ingestion Pathways Input Data, Location $\ldots \ldots \ldots \ldots \ldots \ldots \ldots \ldots \ldots$

B-16. Affected Population by Agricultural Good, Location ......... 46

B-17. Individual Dose by Agricultural Good, Location ........... 47

B-18. Population Annual Dose by Method and Agricultüral

B-19. Population 50-Year "Dose by Method and Agricultural

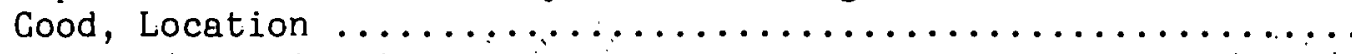




\section{LIST OF CONVERSIONS}

To Convert

miles $(\mathrm{mi})$
square miles $\left(\mathrm{mi}^{2}\right)$
square miles $\left(\mathrm{mi}^{2}\right)$
acres
inches (in)
feet ( $\mathrm{ft})$

Into

kilometers ( km)

square kilometers $\left(\mathrm{km}^{2}\right)$

acres

hectare (ha)

centimeters $(\mathrm{cm})$

meters (m)
Multiply By

1.609

2.590

640.0

0.4047

2.540

0.3048 


\subsection{INTRODUCTION}

Identification and qualification of a site for use as a high-level nuclear waste repository must progress through several intermediate stages before successful completion. In general, new and more defined data become available at each stage of the characterization process. For agriculturerelated radiation dose calculation, this staged data availability raises certain questions:

- At which stages of the site identification and qualification process are data of specific levels of detail required?

- At what point in the process is the money spent to develop data at the next level of detail not justified by a corresponding reduction in uncertainty in the resulting dose estimates?

- Is it preferable to use a sophisticated method with inadequate data or a method comparable in precision with the available data?

This paper addresses the above questions as they relate specifically to the use of agricultural data in assessing radiation dose from ingestion of contaminated foodstuffs during operation, decommissioning, and closure of a high-level nuclear waste repository. The model used to perform the dose calculations is PABLM (INTERA, 1983), and data are from studies conducted for the Salt Repository Project within the Permian Basin and Deaf Smith County, Texas.

Ingestion of contaminated food is one of the three critical pathways of radionuclides to the public. The other two, inhalation of radionuclides and submersion in the plume that contains radionuclide material, are not considered in this paper.

Chapter 2 provides pertinent regulatory background and brief descriptions of the computer model used in this study and of the levels of data availability. Chapter 3 discusses three alternative methods of calculating ingestion doses from radionuclides transported through terrestrial pathways (population, population/food, and food-driven). These methods correspond approximately in complexity with the level of detail of input data available. Chapter 4 outlines the applicable data bases for the five data stages: geologic province, region, area, location, and mass balance. Findings and conclusions are presented in Chapter 5. Appendix A provides an amplified discussion of the basic input parameters used in the computer model, and Appendix B contains the tables of values used to perform the dose calculations. 
THIS PAGE

WAS INTENTIONALLY

LEFT BLANK 


\subsection{BACKGROUND}

One of the key purposes of the Nuclear Waste Policy Act of 1982 is:

...to establish a schedule for the siting, construction, and operation of repositories that will provide a reasonable assurance that the public and the environment will be adequately protected from the hazards posed by high-level radioactive waste and such spent nuclear fuel as may be disposed of in a repository [Section 111(b)(1)].

The ability to estimate the radiation dose received by the population through the ingestion of agricultural goods is important in assessing the safety of a high-level nuclear waste repository for the public. According to 10 CFR 20.105 and 20.106, which contain the numerical Limits established by the U.S. Nuclear Regulatory Commission (NRC) for radiation exposures and concentrations of radioactive material in unrestricted areas, the total dose to the public cannot exceed 0.5 rem (500 millirem) per year.

The U.S. Environmental Protection Agency (EPA) offsite preclosure radiological requirements are documented in 40 CFR Part 191. These standards were developed for application to a high-level nuclear waste repository. Regulation 40 CFR 191.03 states:

Management and storage of spent nuclear fuel or high-level or transuranic radioactive wastes at all facilities regulated by the (Nuclear Regulatory) Commission or by Agreement States shall be conducted in such a manner as to provide reasonable assurance that the combined annual dose equivalent to any member of the public in the general environment resulting from: (1) Discharges of radioactive material and direct radiation from such management and storage and (2) all operations covered by Part 190; shall not exceed 25 mrem to the whole body, $75 \mathrm{mrem}$ to the thyroid, and $25 \mathrm{mrem}$ to any other critical organ.

It can be seen here that the limit established by the EPA of 25 millirem per year to the whole body is much more stringent than the NRC limit of 500 millirem per year. Note that this limit is an annual l1mit which applies to the maximum exposed individual. To be certain that the dose limit is not exceeded, it is important, where possible, to reduce the uncertainty in the total dose estimates.

\subsection{DOSE CALCULATIONS USING PABLM}

The main source of radionuclides of concern in this study is the radiation released during disassembly of spent fuel elements. The release vicur's when the end fittings and spacers are removed from the spent fuel assembly so the individual rods may be placed in canisters in a geometrically efficient. manner.

Contamination of food can occur from the direct deposition of radioactive material on plant.s, the uptake of the radioactive material through the root systems of plants, or the uptake of the material by animals that graze on 
plants contaminated with the radionuclides. Once ingested by animals the radioactive material is transferred to the flesh or the milk, which is then consumed by people.

To evaluate the ingestion exposure pathway, the types of crops and animals raised in the area of the site must be known. Agricultural parameters such as growing periods, storage times, acreage, and crop yields must also be known so that the radionuclides can be properly accounted for in the food chain. The following discusses the model and the site-specific agricultural parameters used to assess the ingestion pathway.

The computer code PABLM (INTERA, 1983) has been used to model the ingestion pathway. PABLM includes a large number of biosphere pathway submodels that evaluate the transport of radionuclides through various terrestrial pathways. The code is capable of handling 19 ingestion pathways, including vegetable crops, grains, animal products, seafood, and water, as well as four. external exposure pathways.

For all exposure pathways, radionuclides can be specified to be deposited over an extended period of time and are assumed to be removed from the soil only by radioactive decay. Leaching from the soil and other removal mechanisms which could act to decrease exposure are not taken into account.

PABLM can take into consideration both waterborne and airborne radionuclide releases, which are the expected cases for repository preclosure operations. The code uses dispersion parameters $(x / Q s)$ to calculate the deposition rate of the radionuclides onto the plants and soil. Plant accumulation factors, which are built into libraries in the code, are used to relate the concentrations deposited to the concentrations in the plants. The concentration of nuclides in animal products, such as milk and meat, depends on the animals'. consumption of contaminated forage and the radionucl ide noneentrations in that forage. The ultimate exposure to humans 1 s dependent on the rate at which the contaminated food is ingested and the radionuclide consentration in the foodstuff at the time of ingestion, which is in turn dependent on the radioactive decay during storage of the food.

In calculating the internal dose to an individual, the code can model the exposure to any of 23 organs from a mixture of $10 n$ radinnuclides. The organ doses are based on the model documented in Publication 2 of the International Commission on Radiological Protection (ICRP, 1959) for internally deposited radionuclides. Either the 1-year dose or a dose commitment from an extended release can be calculated. Also, the dose to the maximum exposed individual or the exposure to a population can be computed.

The external exposure pathways also. use the concentration of the deposited nuclides. Using external. dose conversion factors and time in contact with the external radiation fields (i.e., time spent swimming in contaminated water or time working in contaminated fields), the code calculates an external exposure. In the case of the radionuclides that are a concern during preclosure, external exposure does not contribute to the overall dose.

The output of the code includes the exposure by organ and radionuclide, and by organ and food type, in a tabular form. 
PABLM requires input to perform the ingestion dose calculations. The sensitivity analysis of some of the input parameters is given in Appendix $A$. These input parameters are as follows:

1. Food type. Food types represent the food pathways available in PABLM that are viable exposure pathways within the area surrounding the site. For the purposes of the assessment, this area was assumed to lie within a 50-mile radius of the site.

2. Acres grown. This parameter represents the area devoted to growing each food type within the surrounding area. It is used in calculating the affected population, which is discussed below.

3. Animal product. This value represents the weight of animal product produced in the area. As with the acres grown parameter, this value is used to establish an affected population value.

4. Growing period. This value represents the time period from planting to harvest and is used in the code to model the buildup of radionuclides in the food chain. However, the radionuclides that are of concern in this analysis all build up quickly. Therefore, this parameter is not very significant (see Appendix A).

5. Yield. This value represents the production of the crop in kilograms per square meter, an average value for the surrounding area for the food type. The value is determined by calculating a yield weighted by food type component. For example, the yield for leafy vegetable is calculated by multiplying the yields of lettuce, cabbage, spinach, etc., by the acres of each component and then dividing by the total acreage of the food type. Therefore, if one food type component. is more prevalent, it will be reflected in the yield. In the case of the animal products, this value represents the yield of the forage, either hay, corn, sorghum, or other grains.

6. Consumption rate. This is the average annual consumption rate in kilograms of a given food type by a single individual.

7. Affected population. This value is determined by multiplying the area grown (in square meters) by the yield (in kilograms per square meter per year) and then dividing by the individual consumption (in kilograms per year per person). This value then represents the number of people fed by the food grown. In the case of animal products, the production weight per year is divided by the appropriate consumption rate.

Another parameter that is used by PABLM is the atmospheric dispersion characteristics of the area of inlerest. The code requires that a $x / Q$, $a$ dispersion factor based on wind speed and air stability class, be supplied as input. For this analysis, an average $x / Q$ value for the surrounding area was calculated by integrating the function of $X / Q$ and distance over the 50-mile radius. This assumes that the foodstuffs are grown uniformly throughout the area within this radius. Another input to the code is the storage time of the foodstuff after harvest to account for radioactive decay. For this analysis, 
the storage time is assumed to be zero; i.e., no credit is taken for radioactive decay.

\subsection{THE FIVE DATA STAGES}

This paper defines five stages of data availability, which parallel the stages of repository site focus. The five stages of data availability are the geologic province, the region, the area, the location, and mass balance:

1. The geologic province for this study is the States that contain the Permian Basin, a major salt bed. These States are Texas, Oklahoma, New Mexico, Colorado, and Kansas.

2. The region is the land over the Permian Rasin, a large salt bed basin.

3. The area is the land over the Palo Duro Basin. The Palo Duro Basin is a subbasin of the Permian Basin and is located in the northcentral part of the Texas Panhandle.

4. The location is within a 50-mile radius around a point in northern Deaf Smith County, Texas.

5. The mass balance is an in-depth study of the data within a 50-mile radius around a point in northern Deaf Smith County.

Data are available for the first four stages; for the last, mass balance, data are not yet available. 


\subsection{METHODS}

As discussed in Section 2.1 on dose calculations, the PABLM computer code is used to assess the dose delivered to the public living within a 50-mile radius of a high-level nuclear waste repository. The dose is calculated for both the maximum exposed individual and the:population affected by the release. The results are in terms of both an annual dose and a 50-year dose commitment and are calculated only for exposure to radionuclides through the food ingestion pathway. Three different methods were used to calculate the dose. These three methods are discussed below.

\subsection{METHOD A: POPULATION-DRIVEN ASSESSMENT}

Method $A$ assumes that the total population within a 50-mile radius of the repository site is affected through the ingestion pathway. This means that the quantity of crops grown within the affected area is enough to feed the entire population within that area. Also, no person outside this radius will eat the contaminated crops.

The first step of the assessment is to set up the inputs for PABLM. Necessary agricultural-input parameters include food type, crop growing period, crop yield, crop storage time, consumption rate, and translocation. Data used for the calculations are described in Chapter 4 . When available data did not correspond to input needs, the input parameter was established by forming ratios between other parameters. For example, a consumption value for grain is given in the geologic province data set. Since two grains, wheat and corn, are present, PABLM needs a consumption value for each of the grains. The acreage of wheat is divided by the acreage of grain and the ratio multiplied by the consumption value for grain. This calculation results in a consumption value for wheat. The remainder is the grain consumption value for corn.

The next step is to run the code for the average and maximum exposed individual cases. The output of the code consists of the dose to different body organs of concern: total body, bone, lungs, and thyroid. The whole-body dose is calculated by combining the weighted doses from each organ. The weighted doses are calculated by multiplying the organ doses by weighting factors given in ICRP Publication 26 (1977). For the organs in this assessment the factors are 1.0 for total body, 0.12 for bone, 0.12 for lungs, and 0.03 for thyroid. The combined whole-body dose is the average exposed individual's dose. This whole-body dose is then multiplied by 1.5 to get the maximum exposed individual's dose. The 1.5 value allows for the maximum exposed individual's greater consumption of food.

Finally, the population dose is calculated. For method A, the population dose equals the average individual's dose multiplied by the total population living within a 50-mile radius of the site. 


\subsection{METHOD B: POPULATION/FOOD PRODUCTION-DRIVEN ASSESSMENT}

Method $B$ is similar to method $A$ in that the maximum exposed individual's dose is calculated the same way. The difference is in the manner of calculating the population dose. In method B, the number of people affected by $a$ food type is dependent on the quantity of food available for consumption. However, as in method $A$, the maximum number of people that can be affected is the total population within a 50-mile radius of the site. In other words, if the quantity of a crop grown will not support the total population of the area, its effect is assessed only for the number of people who could eat that crop. As in method $A$, no person outside the affected area will consume the contaminated crop.

First the population dose is calculated by assessing the average individual's dose from each of the food types. This dose is then multiplied by the number of people who could eat the quantity of crop grown, up to the total population value for the area. The contributions from each food type are summed to arrive at a total population dose. The maximum value for the population dose by this method is the same as the one yielded by method $A$.

\subsection{METHOD C: FOOD PRODUCTION-DRIVEN ASSESSMENT}

Method $C$ is different from methods $A$ and $B$ in the way it treats the population exposure. In this case, the number of people who are exposed to the contaminated foodstuffs depends solely on the amount of food grown within the affected area. Therefore, the affected population is all persons who eat the contaminated food, regardless of where they live. With this method, it is assumed that all the crop grown in the area is available for human. consumption.

The maximum exposed individual's dose for method $C$ is caloulated the zame way as in methods $A$ and $B$. The population dose calculations for this method are the same as for method $B$. The only difference is that the total population that could be fed by the crop is used as the population value for each of the food types. In an area with a large amount of agricultural activity, method $\mathrm{C}$ yields the highest population doses. Method $\mathrm{C}$ can be thought of as a global dose assessment, because the effects of the radionuclide release are being assessed outside the area of interest. 


\subsection{DATA BASES FOR THE FIVE STAGES}

This chapter discusses the data that are available at each of the five" data stages. Information to be considered for the dose calculations includes data on climate, population, consumption rates and types, growing periods, yield, acreage, utilization, and transportation of the agricultural goods grown in the area.

Much of the agricultural and population data are given in acres and square miles, since these are the basic units used in agriculture at this time. A list of conversions (to metric units) is provided at the front of this report.

\subsection{GEOLOGIC PROVINCE}

The geologic province as defined in this study is the southwest area of the nation, which contains the Permian Basin. This area includes Kansas, Colorado, Oklahoma, Texas, and New Mexico (see Figure 4-1). The Permian Basin is located in the Southern Plains and Lowlands climate zones. In general, climatic changes are gradual across the zone because there are no significant climate barriers. Differences in climatic conditions within this zone are controlled primarily by latitude, general air mass and storm movements, elevation, and distance from sources of moisture.

The province is predominantiy continental, with cold winters and warm to hot summers. The western portion has a dry climate because of the blocking and orographic effect of the mountains to the west. The eastern portion has a warm, humid, and rainy climate due to the modifying effects of the Gulf of Mexico. The northern portion is affected by polar air masses, frequently during the winter and less frequently in the summer.

The population of this geologic province is sparse. In the 1980 census, Kansas had a population of 2,363,000; Colorado, 2,889,000; and Oklahoma, $3,025,000$. Texas had the highest population with $14,228,000$ and New Mexico the lowest with 1,300,000 (Bureau of the Census, 1984). The average population per square mile for these states is $28.7,27.7,43.5,53.3$, and 10.7, respectively with an average value of 32.8 persons per square mile for the geologic province. Since it is not known at this stage of characterization what percentage of the total population lives in rural areas, urban areas, or cities, this is only a rough approximation of the population near the site.

The types of crops grown in the province were taken from a list of the principal agricultural commodities in each of the five States. The top four commodities for each State, in order of marketing receipts, and the State rank for total farm marketing are listed in Table 4-1. The information in this table suggests that the top four crops in the geologic province for ingestion calculation purposes are cattle, wheat, dairy products, and corn, in that order (cotton is overlooked since it is not typically a food crop). Sorghum and hay are presumed to be given to the livestock as feed.

The population oonsumption rates used for the province are the rates given in U.S. Nuclear Regulatory Commission (NRC) Regulatory Guide 1.109 (NRC, 


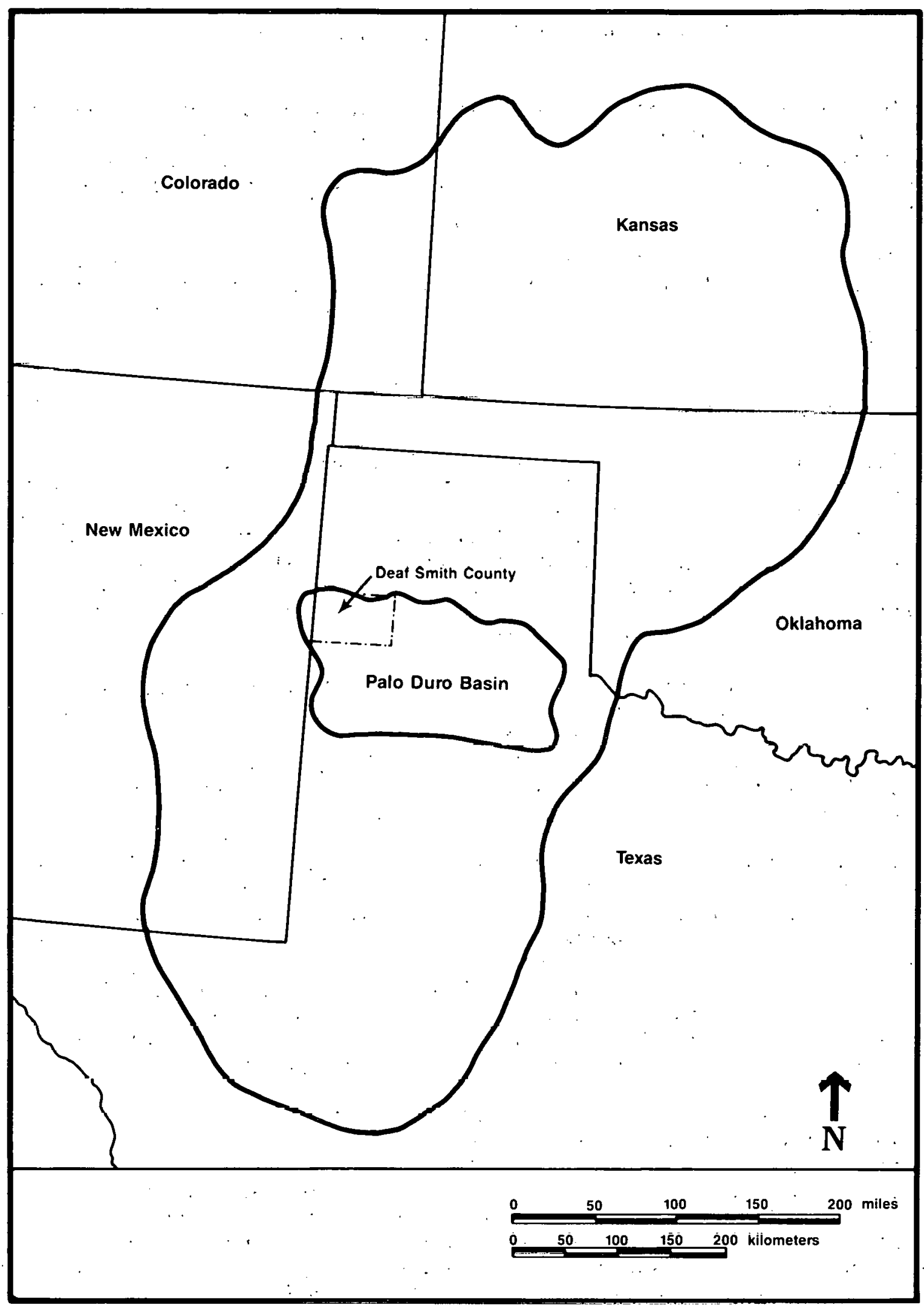

Figure 4-1. The Permian Basin 
Table 4-1. States' Top Four Agricultural Commodities

\begin{tabular}{llc}
\hline \multicolumn{1}{c}{ State } & \multicolumn{1}{c}{ Crops } & Rank $(a)$ \\
\hline Texas & Cattle, cotton, wheat, sorghum grain & 3 \\
Kansas & Cattle, wheat, sorghum grain, corn & 7 \\
Oklahoma & Cattle, oats, dairy products, cotton & 16 \\
Colorado & Cattle, wheat, corn, dairy products & 18 \\
New Mexico & Cattle, dairy products, hay, wheat & 36 \\
\hline \hline
\end{tabular}

(a) National rank of total from marketing.

Source: Bureau of the Census, 1984.

1977). The consumption rates for the crops in question are given in Table 4-2. These are the recommended consumption rates to be used for the average individual in lieu of site-specific data.

The growing periods for the crops to be used at this level are generic values for the crop types specified. The yields are the weighted average yields of the five States that contain the Permian Basin. The acreage is the total number of acres of the crops grown in each state. The transportation information is taken from NRC Regulatory Guide 1.109 (NRC, 1977). The agricultural information is shown in Table 4-3.

The total area of the geologic province is approximately $644,608 \mathrm{mi}^{2}$ $(412,549,120$ acres $)$.

The information available at the geologic province level is a crude representation of the agricultural setting of the site. Only the major cash crops are known; no information exists on crops that are less abundant but significant in the ingestion dose pathways. Therefore, there is little confidence in the maximum exposed individual dose assessment. Also, the affected populations can be only roughly estimated because the crop usage is not known. Therefore, the results of the population dose assessment cannot be reported with much confidence. However, of the three methods, there is less uncertainty in using methods $A$ and $B$ than in using method $C$.

\subsection{REGION}

The region of study is the Permian Basin, a large salt bed region which lies in the southwestern part of Kansas, the southeastern corner of Colorado, the western half of Oklahuma, the eastern quarter of New Mexico, and the northern panhandle portion of Texas (see Figure 4-1). This salt basin has 
Table 4-2. Recommended Values for Consumption for the Average Individual in Lieu of Site-Specific Data

\begin{tabular}{cccc}
\hline \hline Crop & Child & Teen & Adult \\
\hline Grain $(\mathrm{kg} / \mathrm{yr})$ & 48.0 & 57.6 & .45 .6 \\
Milk $(\mathrm{L} / \mathrm{yr})$ & 170.0 & 200.0 & $110 . \dot{0}$ \\
Meat $(\mathrm{kg} / \mathrm{yr})$ & -37.0 & 59.0 & 95.0 \\
\hline
\end{tabular}

Source: NRC, 1977.

Table 4-3. Agricultural Information for the Geologic Province

\begin{tabular}{ccccc}
\hline \hline Crop & $\begin{array}{c}\text { Growing Period } \\
\text { (days) }\end{array}$ & $\begin{array}{c}\text { Yield } \\
\left(\mathrm{kg} / \mathrm{m}^{2}\right)\end{array}$ & $\begin{array}{c}\text { Acreage } \\
\text { (thousand acres) }\end{array}$ & $\begin{array}{c}\text { Transport Time } \\
\text { (days) }\end{array}$ \\
$\begin{array}{c}\text { Wheat } \\
\text { Corn }\end{array}$ & 90 & 0.24 & $24,239$. & 14 \\
\hline & 90 & 0.91 & $3,455$. & 14 \\
Animal Product & $\begin{array}{c}\text { Grumig Periud } \\
\text { (days) }\end{array}$ & $\begin{array}{c}\text { Forage } \\
\left(\mathrm{kg} / \mathrm{m}^{2}\right)\end{array}$ & $\begin{array}{c}\text { Production } \\
(\text { million } \mathrm{kg})\end{array}$ & $\begin{array}{c}\text { Transport Time } \\
\text { (days) }\end{array}$ \\
\hline Beef & 90 & $1.1(\mathrm{a})$ & $4,680$. & 20 \\
Milk & 30 & $1.1(\mathrm{a})$ & $2,920$. & 4 \\
\hline \hline
\end{tabular}

(a) Corn-based grain feed. 
been characterized for the Salt Repository Project, and the data collected at the regional stage are used here (NUS, 1983).

The climate of the Permian Basin region is the same as the climate for the geologic province. The Permian Basin is located in the Southern Plains and Lowlands climate zones. The prevailing winds in the Permian region are from the southwest through south-southeast. The annual mean wind speed ranges from a minimum of 9.0 miles per hour in New Mexico at the eastern edge of the basin to the maximum value of 14.1 miles per hour in southern Kansas.

The total area of the Permian Basin is approximately 189,000 square miles $(120,960,000$ acres $)$ and the population of this region is sparse. The population information used for the region is the same as that used for the geologic province, but each State is weighted by the approximate percentage of the Permian Basin that it includes. Using these weighting factors (given in Table 4-4), the total population for the Permian Basin is 7,202,000 with a density of 38.3 per square mile. Again, this is only a rough estimate, since population centers have not been taken into account.

The types of crops produced in the Permian Basin are the same as those produced in the geologic province; the major crops are cattle, wheat, dairy products, and corn. Sorghum is presumed to be used in a corn-based feed for cattle. The population consumption rates used for the region are the recommended consumption rates given in Table $4-2$.

The agricultural data used for the region are given in Table 4-5. The growing periods and transport times are the same NRC default values that were used for the geologic province. The acreage and yield information have been calculated using the weighting factors in Table 4-4 on the individual State agricultural data used for the geologic province.

The information available at the regional level is more reliable than that reported in the geologic province section. Because a smaller land area is involved, the food types and their production are known to a greater degree. Still, only major crop data are reported and no credit is given for vegetables and other crops grown in less abundance. Again, this reduces the confidence in the maximum exposed individual dose assessment. Also, the usage of the food types is not well documented; therefore, the affected populations are difficult to approximate. This means that methods $A$ and $B$ are more useful than method $C$.

\subsection{AREA}

The area that is under study is the Palo Duro Basin (see Figure 4-1). The Palo Duro Basin is a subbasin of the Permian Basin and is located in the north-central section of the Texas Panhandle. It covers an area of approximately 13,000 square miles $(8,320,000$ acres). Most of the information used here was retrieved from ONWI-102, Area Environmental Characterization Report of the Dalhart and Palo Duro Basins in the Texas Panhandle (NUS, 1982).

The climate of the Palo Duro Basin is semiarid; the basin is located between the Ary, desert climate to the west and the wet, humid climate to the 
Table 4-4. Permian Basin State Weighting Factors

\begin{tabular}{lc}
\hline \hline State & $\begin{array}{c}\text { Weighting Factor } \\
\text { (percent) }\end{array}$ \\
Kansas & 26.5 \\
Colorado & 5.5 \\
Oklahoma & 13.5 \\
New Mlexluo & 13.5 \\
Texas & 41.0 \\
\hline
\end{tabular}

Table 4-5. Agricultural Information for the Region

\begin{tabular}{ccccc}
\hline \hline Crop & $\begin{array}{c}\text { (irnwing Perind } \\
\text { (days) }\end{array}$ & $\begin{array}{c}\text { Yield } \\
\left(\mathrm{kg} / \mathrm{m}^{2}\right)\end{array}$ & $\begin{array}{c}\text { Acreag8 } \\
\text { (thousand acres) }\end{array}$ & $\begin{array}{c}\text { Transport Time } \\
\text { (days) }\end{array}$ \\
\hline $\begin{array}{c}\text { Wheat } \\
\text { Corn }\end{array}$ & 90 & 0.24 & $5,717$. & 14 \\
& 90 & 0.88 & 946. & 14 \\
Animal Product & $\begin{array}{c}\text { Growing Period } \\
(\text { days })\end{array}$ & $\begin{array}{c}\text { Eorage } \\
\left(\mathrm{kg} / \mathrm{m}^{2}\right)\end{array}$ & $\begin{array}{c}\text { Production } \\
\text { (million } \mathrm{kg})\end{array}$ & $\begin{array}{c}\text { Transport Time } \\
\text { (days) }\end{array}$ \\
\hline Beef & 90 & $1.1(\mathrm{a})$ & $1,300$. & 20 \\
Milk & 30 & $1.1(\mathrm{a})$ & 863. & 4 \\
\hline
\end{tabular}

(a) Corn-based grain feed. 
east and southeast. Most of the area is steppe, characterized by sparse vegetation, warm temperatures, and periods of little precipitation.

Table 4-6 provides the annual distributions of atmospheric stability classes for Amarillo and Lubbock, Texas. Amarillo is on the northern boundary of the basin. Lubbock is just south of the basin. In the western portion of the Palo Duro Basin the analysis of atmospheric data shows that dispersion conditions are relatively good at all times of the year. Because of variations of the local terrain in the eastern portion of the basin, dispersion conditions are more dependent on the actual site location, but dispersion conditions of well-exposed locations can be expected to be similar to those in. the western portion.

The annual average wind speed is 22.0 kilometers ( 13.7 miles) per hour for Amarillo and 20.4 kilometer.s ( 12.7 miles) per hour for Lubbock.

As with the province and region, the population of the area is sparse. Table 4-7 lists the counties that are in the Palo Duro Basin, their approximate percentages of the basin, their population (Dallas Morning News, 1983) and their population density. Using Table 4-7 to produce a weighted average, the average number of persons per square mile in the Palo Duro Basin is 16.4 and the total population of the basin is 193,756. Table 4-8 gives the population and population density for the counties that are near the Palo Duro Basin. A large fraction of the population in the Palo Duro Basin is located in the larger population centers such as Amarillo, Hereford, Plainview, Canyon, Tulia, and Seth Ward.

The Palo Duro Basin is one of the most important agricultural regions in Texas. Several of the counties within the basin are the State's top producers of field crops, grain crops, vegetables, and cotton. The major field crops produced in the Palo Durn Rasin are corn, soybeans, sorghum, sugar beets, and sunflowers. The major grain crops are wheat, barley, and rye. The vegetable crops, including cabbage, cantaloupes, carrots, cucumbers, lettuce, onions, bell peppers, and potatoes, are highly concentrated in relatively small areas. Cotton is grown, but is not taken into account for ingestion doses. Cattle is the main livestock of the area.

The population corisumption rates used for the area are those recommended by the NRC for use in lieu of site-specific data, shown prevlously in Table 4-2. Table 4-9 adds to these values the vegetable consumption rates.

The agricultural data used for the area stage are given in Table 4-10. The transport time and growing period are the same generic terms that were used before, while the acreage and yield information are from the Texas Department of Agriculture (Texas Crop and Livestock Reporting Service, 1984a, b, and c; 1985).

There is a larger amount of data available for the area characterization than for the geologic province or regional characterizations. The introduction of a larger variety of the food types grown in the area helps to reduce the uncertainty of the maximum individual dose assessment. The amount of acreage devoted to each food type is more accurately known, which reduces the uncertainty in the population dose assessment. Still, how the crops are used 
Table 4-6. Annual Atmospheric Stability Classes for Amarillo and Lubbock

\begin{tabular}{|c|c|c|c|c|c|c|c|}
\hline \multirow{3}{*}{ Location } & \multirow{2}{*}{\multicolumn{3}{|c|}{ Unstable }} & Stabili & Class & & \\
\hline & & & & \multicolumn{2}{|c|}{ Neutral } & \multicolumn{2}{|c|}{ Stable } \\
\hline & $\bar{A}$ & B & $\bar{C}$ & $\bar{D}$ & $\bar{E}$ & $\bar{F}$ & $\bar{G}$ \\
\hline Amarillo & 0.30 & 2.03 & 9.08 & 68.94 & 14.69 & 4.41 & 0.55 \\
\hline Lubbock & 0.55 & 4.18 & 12.16 & 54.32 & 14.92 & .11 .19 & 2.68 \\
\hline
\end{tabular}

Table 4-7. Population and Areal Relationships of the Palo Duro Basin and Texas Counties

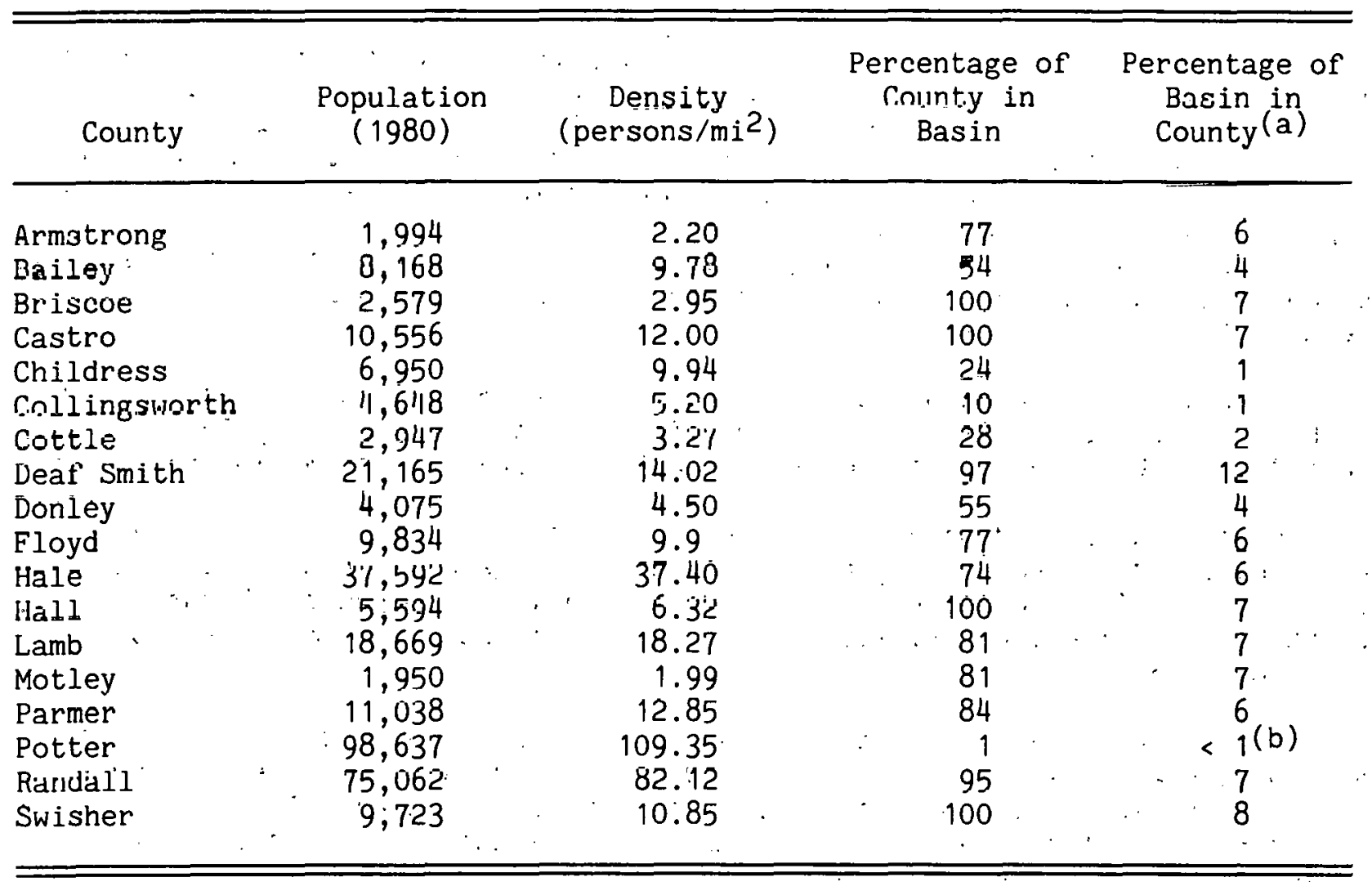

(a) Total less than 100 percent due to rounding.

(b) Assumed to be 0.1 percent. 
Table 4-8. Populations for Counties Near the Palo Duro Basin

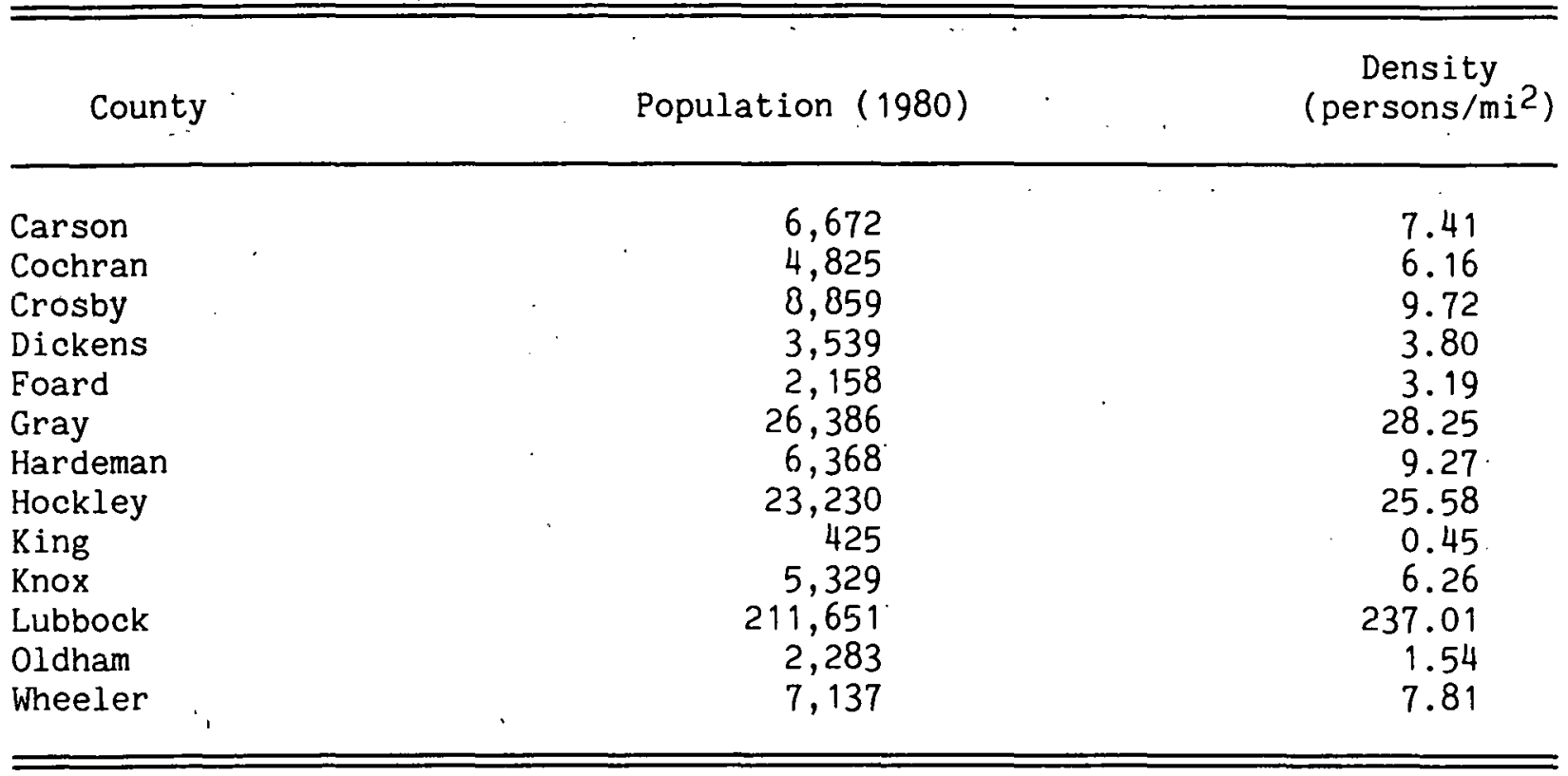

Table 4-9. Recommended Values for Consumption Rates for the Average Individual in Lieu of Site-Specific Data

\begin{tabular}{lrrr}
\hline \hline Crop & Child & Teen & Adult \\
\hline Vegetable $(\mathrm{kg} / \mathrm{yr})$ & 108.0 & 129.6 & 102.6 \\
Grain $(\mathrm{kg} / \mathrm{yr})$ & 48.0 & 57.6 & 45.6 \\
Milk ( $/ \mathrm{yr})$ & 170.0 & 200.0 & 110.0 \\
Meat $(\mathrm{kg} / \mathrm{yr})$ & 37.0 & 59.0 & 95.0 \\
\hline \hline
\end{tabular}

Source: NRC, 1977. 
Table 4-10. Agricultural Information for the Area

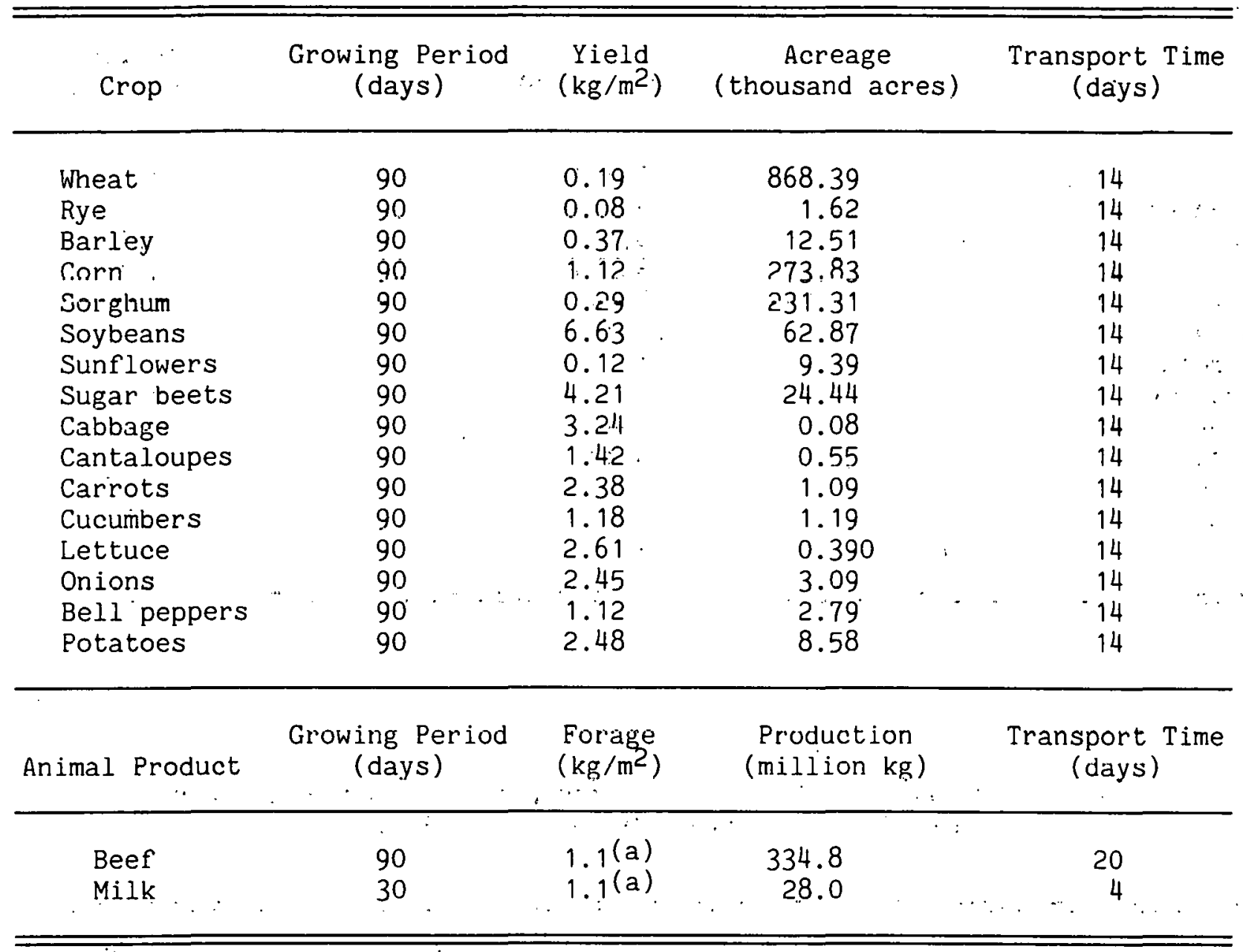

(a) Corn based grain feed. 
is not included in the data base at this stage. This means that methods $A$ and $B$ are more useful than method $C$.

\subsection{LOCATION}

Data for the location stage are pertinent to the area within a 50-mile radius from a point in the north-central part of Deaf Smith County in the Southern High Plains of the Texas Panhandle. This point is centered at latitude $35^{\circ} 07^{\prime} \mathrm{N}$ and longitude $102^{\circ} 29^{\prime} \mathrm{W}$. The source for most of the data is BMI/ONWI-541, Rev. i (Waite et al., 1986). Deaf Smith County is pictured in Figure 4-1.

The location climate is typical of the Palo Duro Basin; it is a semiarid climate, with warm temperatures, and periods of little precipitation, supporting a sparse natural vegetation. As measured in Amarillo, precipitation averages about 19 inches per year, and the average annual runoff is less than 1.0 inch. Together with an average wind speed of $13.8 \mathrm{miles}$ per hour, these semiarid conditions create a high potential for wind erosion. However, they also favor the dispersion of pollutants in the atmosphere. The location weather includes tornadoes, thunderstorms, and heavy fog. The atmospheric stability classes for Amarillo are given in Table 4-6.

The population within the 50-mile radius is 217,000 . This gives a population density of 27.63 persons per square mile. The total population within this radius is greater than the population stated for the Palo Duro Basin because the 50-mile radius around the site includes parts of the city of Amarillo, which is not included in the Palo Duro Basin.

The types of crops grown at the location include lettuce, cabbage, sweet corn, cucumbers, bell peppers, potatoes, carrot.s, onions, tomatoes, cantaloupes, watermelons, wheat, barley, and oats. The types of livestock produced include cattle, hogs, and poultry. Dairy products are also produced.

The population consumption rates to be used for the Deaf Smith County location are national consumption rates given by the U.S. Department of Agriculture (1984). The consumption rates are shown in Table 4-11.

The agricultural data used are given in Table 4-12. The transport time and growing period are the same generic terms used for the other study regions, while the acreage and yield information were taken from Texas Department of Agriculture publications (Texas Crop and Livestock Reporting Service, 1984a, b, and c; 1985).

The location stage represents the most detailed data available to date. There is a wide variety of food types reported and the field data (e.g., yield and acreage) are more precise. This added knowledge, as well as better consumption data, result in a confident maximum individual dose assessment. Also, the population dose assessments by methods $A, B$, and $C$ are more reliable, because of a more reliable estimation of the affected population. 
Taile 4-11. Deaf Smith County Location Consumption Rates

\begin{tabular}{|c|c|c|c|c|c|c|c|c|c|c|c|c|c|c|}
\hline & Food Type & & & & & & & & & Con & $\begin{array}{l}\text { umption } \\
/ \mathrm{yr} / \text { persc }\end{array}$ & $\begin{array}{l}\text { Rate } \\
\text { son) }\end{array}$ & & \\
\hline 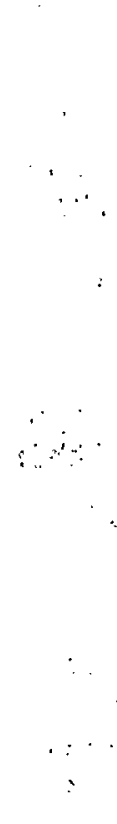 & $\begin{array}{l}\text { Lettuce } \\
\text { Cabbage } \\
\text { Sweet corn } \\
\text { Cucumbers } \\
\text { Bell püpuer's } \\
\text { Potatoes } \\
\text { Carrots } \\
\text { Onions } \\
\text { Sweet potatoes } \\
\text { Tomatoes } \\
\text { Cantaloupes } \\
\text { Watermelons } \\
\text { Wheat } \\
\text { Barley } \\
\text { Oats } \\
\text { Beef } \\
\text { Pork } \\
\text { M1lk } \\
\text { Poultry }\end{array}$ & $\begin{array}{l}\cdot \\
. \\
\cdot \\
\cdot \\
\cdot \\
\text { s } \\
. \\
. \\
. \\
. \\
. \\
.\end{array}$ & 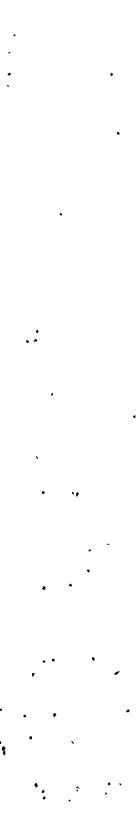 & 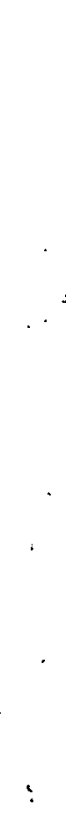 & $\therefore:$ & $\begin{array}{c} \\
\vdots \\
\because \\
\therefore\end{array}$ & & $\cdots$ & 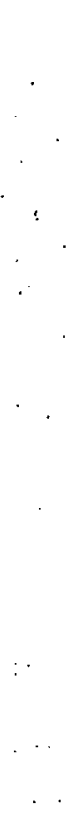 & 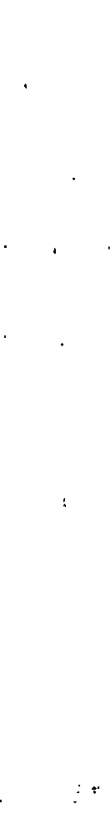 & $\begin{array}{r}11.0 \\
3.5 \\
2.9 \\
1.9 \\
1.5 \\
24.6 \\
3.1 \\
5.2 \\
1.6 \\
5.1 \\
2.8 \\
5.0 \\
54.0 \\
0.9 \\
3.1 \\
35.2 \\
28.9 \\
111.4 \\
28.6\end{array}$ & $\begin{array}{l}\because \\
\therefore \\
\therefore \\
\therefore\end{array}$ & $\begin{array}{l} \\
\ddots \\
\\
\vdots \\
\ddots \\
\ddots \\
\ddots\end{array}$ & 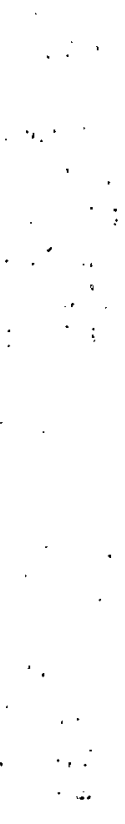 \\
\hline
\end{tabular}


Table 4-12. Agricultural Information for the Location

\begin{tabular}{|c|c|c|c|c|}
\hline Crop & $\begin{array}{c}\text { Growing Period } \\
\text { (days) }\end{array}$ & $\begin{array}{l}\text { Yield } \\
\left(\mathrm{kg} / \mathrm{m}^{2}\right)\end{array}$ & $\begin{array}{c}\text { Acreage } \\
\text { (thousand acres) }\end{array}$ & $\begin{array}{c}\text { Transport Time } \\
\text { (days) }\end{array}$ \\
\hline $\begin{array}{l}\text { Wheat } \\
\text { Barley } \\
\text { Oats } \\
\text { Sweet corn } \\
\text { Cabbage } \\
\text { Cantaloupes } \\
\text { Watermelons } \\
\text { Carrots } \\
\text { Cucumbers } \\
\text { Tomatoes } \\
\text { Lettuce } \\
\text { Onions } \\
\text { BE:l peppers } \\
\text { Potatoes } \\
\text { Sweet potatoes }\end{array}$ & $\begin{array}{l}90 \\
90 \\
90 \\
90 \\
90 \\
90 \\
90 \\
90 \\
90 \\
90 \\
90 \\
90 \\
90 \\
90 \\
90\end{array}$ & $\begin{array}{l}0.1 \\
0.3 \\
0.3 \\
0.8 \\
2.8 \\
1.3 \\
1.2 \\
2.4 \\
1.1 \\
1.0 \\
2.6 \\
2.6 \\
1.1 \\
2.4 \\
1.3\end{array}$ & $\begin{array}{l}270.9 \\
17.6 \\
4.5 \\
0.05 \\
0.08 \\
0.55 \\
0.43 \\
0.70 \\
0.1 \\
0.15 \\
0.390 \\
1.51 \\
0.04 \\
2.91 \\
0.09\end{array}$ & $\begin{array}{l}14 \\
14 \\
14 \\
14 \\
14 \\
14 \\
14 \\
14 \\
14 \\
14 \\
14 \\
14 \\
14 \\
14 \\
14\end{array}$ \\
\hline Animal Product & $\begin{array}{c}\text { Growing Period } \\
\text { (days) }\end{array}$ & $\begin{array}{l}\text { Forage } \\
\left(\mathrm{kg} / \mathrm{m}^{2}\right)\end{array}$ & $\begin{array}{l}\text { Production } \\
\text { (million } \mathrm{kg} \text { ) }\end{array}$ & $\begin{array}{c}\text { Transport Time } \\
\text { (days) }\end{array}$ \\
\hline $\begin{array}{l}\text { Beef } \\
\text { Pork } \\
\text { Poultry } \\
\text { Milk }\end{array}$ & $\begin{array}{l}90 \\
90 \\
90 \\
30\end{array}$ & $\begin{array}{l}1.1(a) \\
1.1(a) \\
1.1(a) \\
1.1\end{array}$ & $\begin{array}{c}193.2 \\
5.40 \\
0.31 \\
22.0\end{array}$ & $\begin{array}{r}20 \\
20 \\
20 \\
4\end{array}$ \\
\hline
\end{tabular}

(a) Corn-based grain feed. 


\subsection{MASS BALANCE}

The mass balance data stage will be the most in-depth of the data stages. All the input data from the location stage will be closely investigated. Each input parameter will be as exact as possible. Surveys and a census will be taken of the surrounding area, which will give site-specific information.

The climate will be monitored by a meteorological station on site. When necessary, climate and weather information will be used from a station near the mass balance site, since there should be only a marginal difference.

The population and food consumption information will be obtained through a census, which will give an exact population of the area around the site and. information on food consumption habits.

The agricultural intormation will be obtained throlgh exact measurcmicnts of the amount, types, and yields of agricultural goods. The importing and exporting of agricultural goods will be measured, as will their averago storage and shipping times. Destination of exported agricultural goods will also be noted. Most importantly, the usage of each crop will be documented.

The amount of information available at this level of study should give the best estimation of the ingestion dose to the public. All the necessary parameters will be measured and taken into account, allowing for confidence in the assessment of both the affected area and global doses. Therefore, at. this stage, method $\mathrm{C}$ is the best method to use. 


\subsection{FINDINGS AND CONCLUSIONS}

The questions asked in the introduction to this paper can now be considered in light of the results obtained using staged data and the three methods of calculation. Table 5-1 summarizes these results.

First, at which stages of the site identification and qualification process are data of specific levels of detail required? The stages of the site identification progressed from a very general to a very specific area. However, for each stage of the site identification process, there were adequate data available to assess the radiological impacts of ingestion radiation doses. These data were general for the larger geographic areas and became more specific as the site was narrowed. Therefore, since the assessment did not demand more specific data at any stage, there was no stage where specific levels of detail were required.

Closely related to the first question, the second is concerned with how more detailed input data pay off with respect to assessment results. The maximum individual and population dose results in Table 5-1 show that there is not much difference in the results from the different stages. Thus, the extra effort in detailing the additional data as the site was better defined does not seem to pay off. Therefore, the amount of money spent in developing more detailed data for all agricultural goods does not have the corresponding effect of producing more accurate assessment results.

One of the reasons that there is not a convergence in the assessment results as the site-selection stages narrow is that the more detailed data available are related to pathways that do not contribute greatly to the final results. For example, the agricultural data related to vegetable types and consumption were developed significantly from geological province to location stage. However, the major dose pathways are from wheat and beef, which were detailed for all of the stages. (See Appendix B for a complete breakdown of the dose contributions of the individual food types.) Therefore, one place where money would be well spent is in developing the data base on how the food types which contribute largely to the total dose are used. This would include the percentages of the food that are actually used for human consumption and, in the case of animal products, the actual radionuclide intake of the animal. These data are very important in determining the total impact of these food types on humans.

The third question asks, is it preferable to use a sophisticated method with inadequate data or a method comparable in precision with the available data? To answer this question, it is necessary to examine the population dose calculation methodologies and results.

Method A, which assumes that everyone living within the assessment area (within a 50-mile radius of the site) is exposed through the ingestion pathway, even if the amount of food grown in the area cannot support everyone, is the case of the method being comparable to the available data. This is the case since there are no data on the food usage. Method $C$, which assumes that the affected population is the number of people who could be supported by the food type if it were all used for human consumption, is an example of a more 
Table 5-1. Maximum Individual Dose and Total Population by Method

\begin{tabular}{|c|c|c|c|c|}
\hline \multirow[b]{2}{*}{ Stage } & \multirow{2}{*}{$\begin{array}{l}\text { Maximum } \\
\text { Individual } \\
\text { (mrem) }\end{array}$} & \multicolumn{3}{|c|}{ Total Population } \\
\hline & & $\begin{array}{c}\text { Method A } \\
\text { (person-mrem) }\end{array}$ & $\begin{array}{c}\text { Method B } \\
\text { (person-mrem) }\end{array}$ & $\begin{array}{c}\text { Method C } \\
\text { (person-mrem) }\end{array}$ \\
\hline Annual Dose & & & . & . \\
\hline Jróvince & $2.9 \times 10^{-2}$ & $4.9 \times 10^{3}$ & $4.9 \times 10^{3}$ & $1.5 \times 10^{4}$ \\
\hline Reglors & $2.9 \times 10^{-2}$ & $5.7 \times 10^{3}$ & $5.7 \times 10^{3}$ & $5.5 \times 10^{11}$ \\
\hline Area & $5.6 \times .10^{-2}$ & $4.8 \times 10^{3}$ & $4.8 \times 10^{3}$ & $2.1 \times 10^{5}$ \\
\hline Location & $4.5 \times \cdot 10^{-2}$ & $6.5 \times 10^{3}$ & $5.8 \times 10^{3}$ & $5.1 \times 10^{4}$ \\
\hline Mass Balance & (a) & (a) & (a) & (a) \\
\hline 50-Year Dose & & & & \\
\hline Provinne & 2.3 & $3.9 \times 10^{5}$ & $3.9 \times 10^{5}$ & $4.6 \times 10^{6}$ \\
\hline Region & 2.3 & $4.5 \times 10^{\circ}$ & $4.5 \times 10^{5}$ & $3.5 \times 10^{6}$ \\
\hline Area & 4.4 & $3.7 \times 10^{5}$ & $3.7 \times 10^{5}$ & $1.3 \times 10^{7}$ \\
\hline Iocation & 2.6 & $3.7 \times 10^{5}$ & $3.3 \times .10^{5}$ & $3.3 \times 10^{6}$ \\
\hline Mass Balance & (a). & (a) & (a) & (a) \\
\hline
\end{tabular}

(a) No characterization data available at this time. 
sophisticated method with inadequate data. Method $\mathrm{C}$ can be thought of as a global assessment, i.e., including affected people outside the assessment area.

Table 5-1 documents the results of the population dose assessment given by these three methods.. Since a global assessment is not required by regulation, and if it is decided that a global assessment is not necessary, then method $A$ would be adequate, yielding results that were conservative and which required little data gathering. Method $B$, which is method $C$ truncated at the assessment area population, gives no significant advantage over method A. ' It must be noted that for areas with very little agricultural output these conclusions may not be valid. There is very large difference between methods $A$ and $C$ because the large agricultural output of the area affects a great number of people. However, since the true affected population values needed for method $C$ were not known, there cannot be much confidence in the results. More realistic results would necessitate a "mass-balance" analysis dose during site characterization, where the disposition of every bit of food is known. Based on the population dose calculation methodologies and results, it is preferable to use a method comparable in precision with the available data.

Other conclusions can be drawn by examining the model. The sensitivity analysis (Appendix A) points out some important relationships among the individual agricultural input parameters of PABLM. For example, there is a direct relationship between consumption and dose and between $x / Q$ and dose. Thus, even if the agricultural makeup of the site is well documented, the use of inadequate meteorological information and human consumption data for the area would adversely affect the analysis. However, for the long-lived radionuclides of interest in the assessment, the growing period and holdup (storage plus transport time) parameters are not very important.

The final conclusion that can be drawn concerns the data gathered during site characterization, i.e., data for the mass-balance analysis. Based on the results shown here, the greatest effort should be focused on gathering meteorological data, human food consumption data, and overall crop usage data. The meteorological data are necessary to develop the atmospheric dispersion parameters used in calculating deposition of released radionuclides. The consumption information is necessary in calculating the intake quantity of contaminated food. Finally, the crop usage data establish how much of the contaminated food type actually goes toward human consumption. Adequate data for these parameters translate into a confident value for the affected population, both within and outside the affected area. Therefore, if the site undergoes site characterization, these will be the key parameters to measure and record for a high confidence in the ingestion dose estimates.

One important point to note is that the conclusions drawn here are based on the results of nily one assessment model and, therefore, are only specific for that model. A close comparison of the performance of PABLM with other agricultural assessment models must be made before final conclusions can be drawn concerning the data needs during site characterization. 
THIS PAGE

WAS INTENTIONALLY

LEFT BLANK 


\subsection{REFERENCES}

\subsection{REFERENCES LISTED BY AUTHOR}

Bureau of the Census, 1984. Statistical Abstract of the United States, 1984, U.S. Department of Commerce, Washington, DC.

Dallas Morning News, 1983. Texas Almanac and State Industrial Guide, 19841985 [sic].

ICRP, see International Commission on Radiological Protection.

INTERA Environmental Consultants, Inc., 1983. PABLM: A Computer Code to Compute Accumulated Radiation Doses From Radionuclides Transported to Aquatic and Terrestrial Pathways in the Biosphere, ONWI-446, prepared for Office of Nuclear Waste Isolation, Battelle Memorial Institute, Columbus, $\mathrm{OH}$.

International Commission on Radiological Protection, 1959. "Report of Committee II of the ICRP on Permissible Dose for -Internal Radiation, "Annals of the ICRP, Publication 2, Pergamon Press, Oxford, England.

International Commission on Radiological Protection, 1977. "Recommendations of the International Commission on Radiological Protection," Annals of the ICRP, Publication 26, Pergamon Press, Oxford, England.

NRC, see U.S. Nuclear Regulatory Commission.

NUS Corporation, 1982. Area Environmental Chracterization Report of the Dalhart and Palo Duro Basins in the Texas Panhandle, Vols. I and II, ONWI-102, prepared for Office of Nuclear Waste Isolation, Battelle Memorial Institute, Columbus, $\mathrm{OH}$.

NUS Corporation, 1983. Environmental Characterization of Bedded Salt Formations and Overlying Areas of the Permian Basin, ONWI-27, prepared for Office of Nuclear Waste Isolation, Battelle Memorial Institute, Columbus, $\mathrm{OH}$.

Texas Crop and Livestock Reporting Service, 1984a. 1983 Texas Field Crop Statistics, Texas Department of Agriculture, Austin, TX.

Texas Crop and Livestock Reporting Service, 1984b. 1983 Texas Livestock, Dairy, and Poultry Statistics, Texas Department of Agriculture, Austin, TX.

Texas Crop and Livestock Reporting Service, 1984c. 1983 Texas Vegetable Statistics, Texas Department of Agriculture, Austin, TX.

Texas Crop and Livestock Reporting Service, 1985. 1985 Texas Sma 11 Grains Statistics, Texas Department of Agriculture, Austin, TX.

USDA, see U.S. Department of Agriculture.

U.S. Department of Agriculture, 1984. Food Consumption, Prices and Expenditures, 1963-1983, Washington, i). 
U.S. Nucleain Regulatory Commission, 1977. "Calculation of Annual Doses to Man From Routine Releases of Reactor Effluents for the Purpose of Evaluating Compliance With 10 CFR Part 50, Appendix I," Regulatory Guide 1.109, Revision 1, Washington, DC, October.

Waite, David A., James J. Mayberry, and Jeffrey M. Furr, 1986. Preclosure Radiological Calculations to Support Salt Site Evaluations, BMI/ONWI-541 (Rev. 1), Office of Nuclear Waste Isolation, Battelle Memorial Institute, Columbus, $\mathrm{OH}$.

6.2 FEDERAL REGULATIONS AND STATUTES

10 CFR Part 20, Standards for Protection Against Radiation.

40 CER Part 191, Environmental Standards for the Management and Disposal of Spent Nuclear Fuel, High-Level and Transuranic Radioactive Wastes. 


\section{APPENDIX A}

\section{: SENSITIVITY ANALYSIS OF PABLM INPUT PARAMETERS}

This appendix discusses six basic ingestion parameters in the PABLM model and how they relate to the dose. Figures $A-1$ through $A-7$. illustrate the relationships using $I-129$.

- Consumption - The consumption value represents the quantity of radioactively contaminated food ingested. This parameter has a linear relationship with dose. Figure A-1 shows a graph of the relationship.

- Translocation - the translocation parameter represents the fraction of the radionuclide deposited on the exterior of a plant that is transferred to the interior. There is a linear relationship between the translocation parameter and dose. When the parameter is equal to zero, the dose is a minimum constant value. The dose increases linearly as translocation increases to its maximum value of 1.0 . The minimum constant value represents the contribution of plant radionuclide inventory from root uptake. For the dose calculations this value was set to 1.0 for leafy vegetables and 0.1 for all other food types. Figure A-2 shows the relationship.

- $X / Q$ - The $X / Q$ parameter represents the atmospheric dispersion characteristics of the area. The lower the $X / Q$ value, the greater the dispersion and, therefore, the lower the concentration. There is a linear relationship between $x / Q$ and dose. This relationship is shown in Figure A-3.

- Holdup - The holdup parameter takes into consideration the radioactive decay of the radionuclides during storage and transport times. Since the radionuclides of concern are long-lived, this value is not important. The relationship between dose and holdup is an exponential reduction in dose with time, with the specific radionuclide decay constant as time is constant. The relationship for I-129 is shown in Figure A-4.

- Growing Period - Growing period is used to calculate the time necessary for the radionuclides to build up in the plant. The longer the half-life of the radionuclide, the faster the buildup. For the radionuclides of concern in the present analysis, this parameter is not very important. Figure A-5 shows the exponential growth from a minimum dose to a saturation value. The minimum dose is the contribution from uptake in roots. The saturation value is 2 percent greater than the 90-day value used in the reference case.

- Yield - The yield represents the quantity of a food type produced per unit of land. The yield is inversely proportional to the dose. That is to say, the highcr the yield, the iower the duse. This is the case because a higher yield dilutes the deposition of 
radionuclides. Figure A- 6 shows the inverse relationship between yield and dose. The dose drops to a minimum value. Again, this minimum value represents the contribution from root uptake, which is not affected by the yield parameter. Figure A-7 shows the relationship between yield and dose with the minimum value subtracted. It can be seen from this figure that the relationship is inversely proportional: 


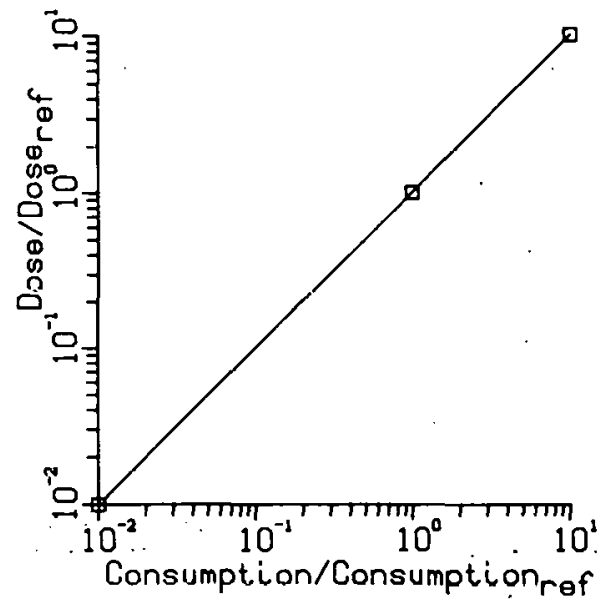

Figure $A-1$.

I-129 Dose Versus Consumption

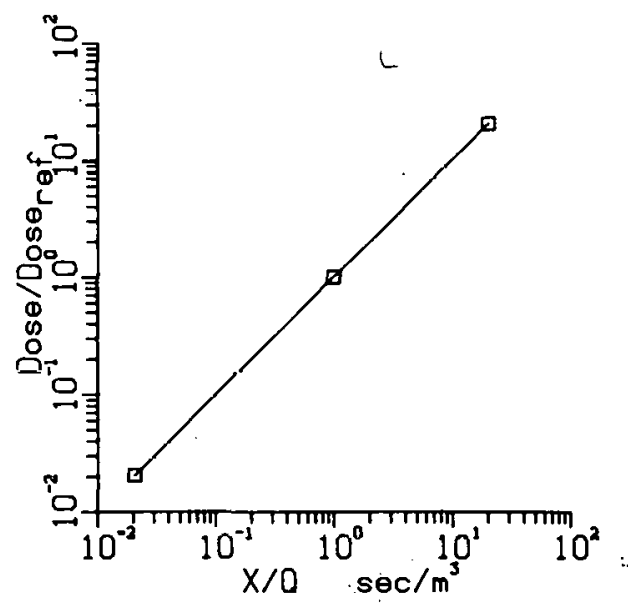

Figure A-3.

I-129 Dose Versus ${ }_{x} / Q$

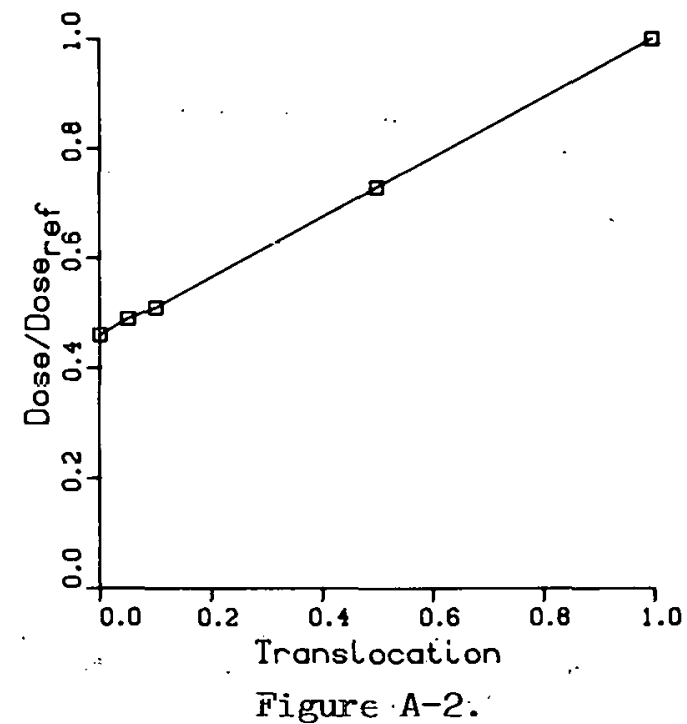

I-129 Dose Versus Translocation

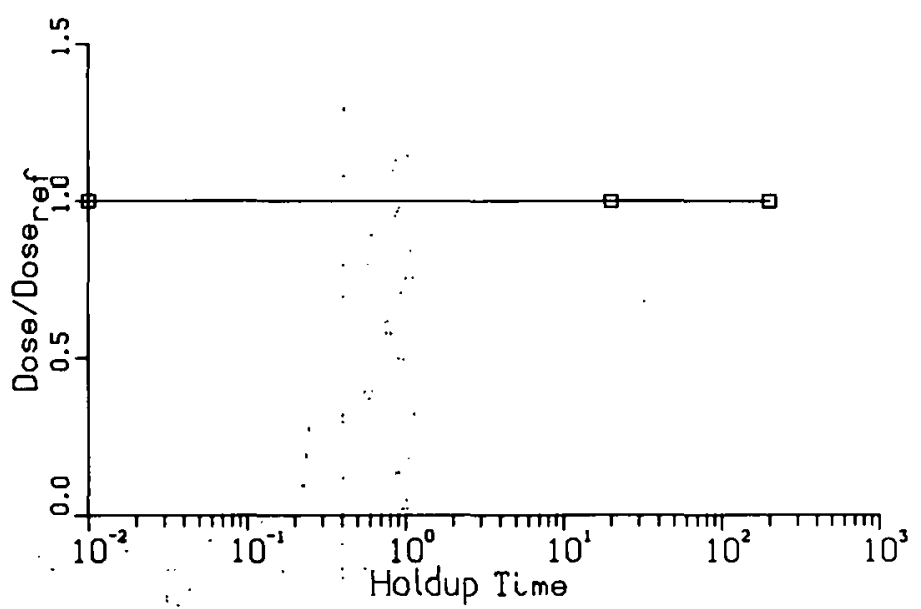

Figure $\cap-?$.

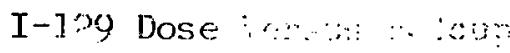




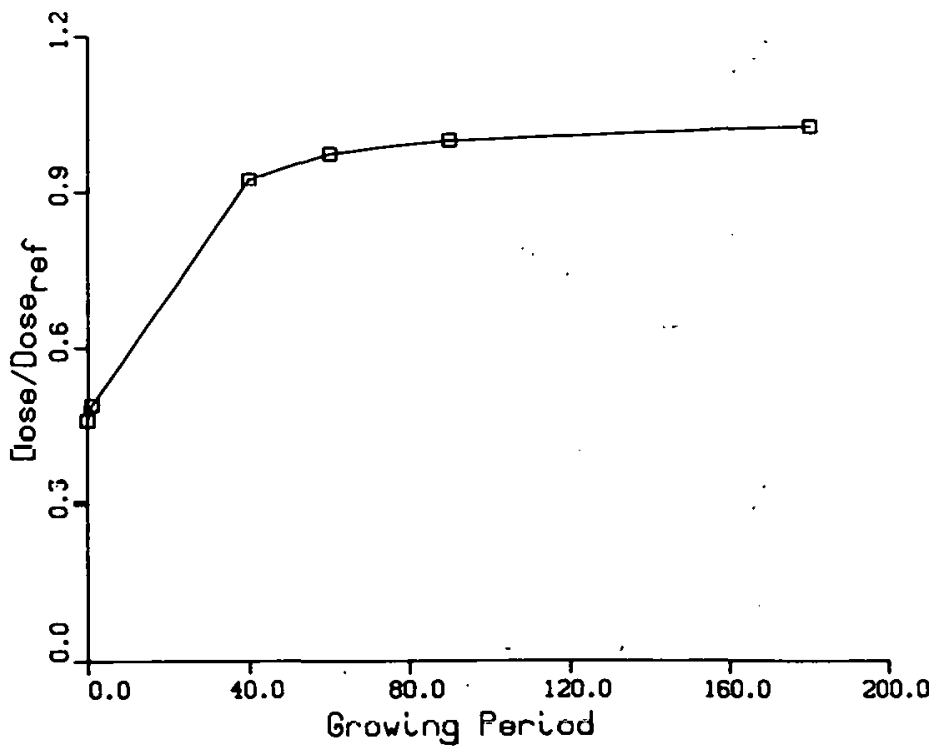

Figure A-5.

I-129 Dose Versus Growing Period

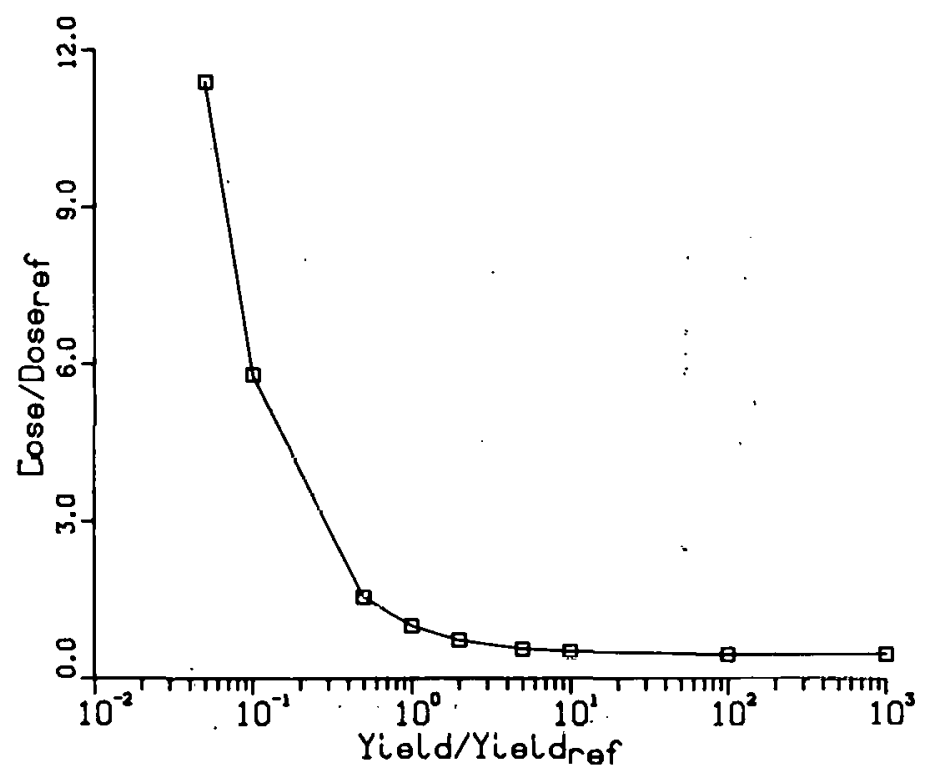

Figure A-6.

I-129 Dose Versus Yielã

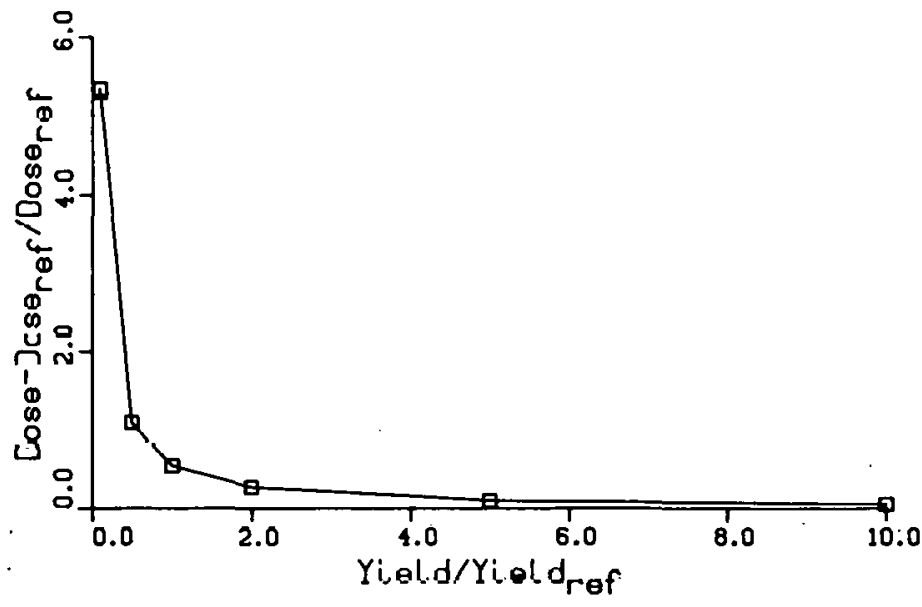

Figure A-7.

I-129 Dose Minus Minimum Value

Versus Yield 
APPENDIX B

VALUES FOR DOSE CALCULATIONS

This appendix contains tables of the values used for the dose calculations for province, region, area, and location stages. It was from these data that the final total ingestion doses were calculated (Table 5-1).

Table B-1. Operational Repository Emission

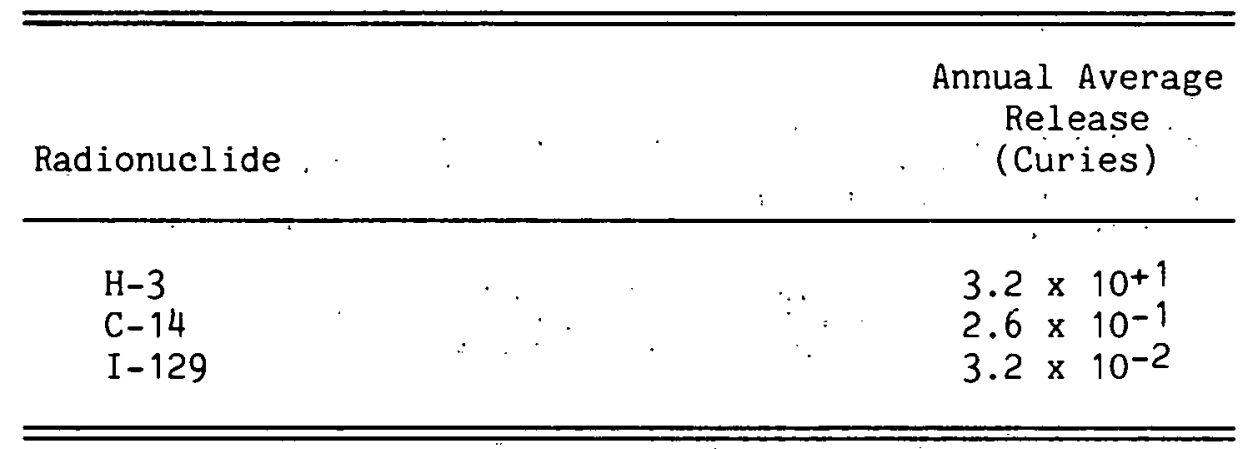

Table B-1 contains the repository emission values used as inputs for the PABLM runs. The $X / Q$ value used for the runs was $4.87 \times 10^{-7}$. A sample of the program output is reproduced in Figure B-1. The dose values shown here are then used to calculate the whole-body dose by multiplying the organ doses by the weighting factors given in Publication 26 of the International Committee on Radiological Protection (ICRP, 1977). For the organs in this assessment the factors are 1.0 for total body, 0.12 for bone, 0.12 for lungs, and 0.03 for thyroid. The combined whole-body dose is the average individual's dose. The total dose is computed by summing the individual agricultural doses. To get the total population dose for each agricultural good the average individual dose is multiplied by the af'fected population. The total dose is again the summation of the individual agricultural goods doses. The maximum exposed individual dose is calculated by multiplying the total average individual dose by 1.5. This process is used to calculate the ingestion dose for both the annual and 50-year dose for each of the four stages of environmental characterization in which data are available.

\section{B. 1 GEOLOGIC PROVINCE}

Tables B-2 through B-5 are for the geologic province calculations. The data in the geologic province tables were produced from Bureau of the Census, 1984 ; and NRC, 1977. 


\section{COMBINED PATHWAY SUMMARY TOTALS PABLM VERSION2 TOTALS BY PATHWAY FOR SPECIFIED ORGANS (INTERNAL DOSES ONLY) CAse TITLE. Dear 3inl lh - Nätlón \\ *** DOSE COMMITMET SUMMARY FOR DOSE-YEAR 1 OF A 26. YEAR PLANT LIfFe ***

\begin{abstract}
IRRIGATION CROP PATHWAY: OFF AIR DEPOSITION CROP PATH: ON
\end{abstract} AQUATIC FOODS PATHWAY: OFF}

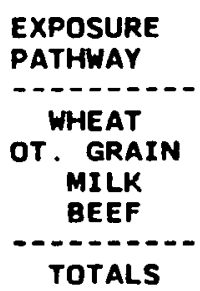

DOSES AND TOTALS REPORTED IN REM

\begin{tabular}{l} 
TOTAL BODY \\
\hline $6.5 E-07$ \\
$5.9 E-08$ \\
$0.5[-07$ \\
$7.9 E-07$ \\
\hline $1.9 E-08$
\end{tabular}

TOTAL BODY

6. 5E- 07

5. $9 E-08$

3. $\mathrm{SE-07}$

1. $9 E-0 B$

\begin{tabular}{l} 
LUNGS \\
\hline $0.0 E+00$ \\
$0.0 E+00$ \\
$0.0 E+00$ \\
$0.0 E+00$ \\
$0.0 E+00$
\end{tabular}

THYROID

-.-.......

2. 6E-04

1. OE-05

8. 05-05

1. 8E-04

5. 4 E-04 


\section{B.2 REGION}

Tables B-6 through B-9 are for the regional calculations. The data in these tables were produced from U.S. Bureau of the Census, 1984; and NRC, 1977.

\section{B.3 AREA}

Tables B-10 through B-14 are for the area calculations. The data in these tables were produced from NUS, 1982; Dallas Morning News, 1983; and Texas Crop and Livestock Reporting Service, 1984a, b, c; 1985.

\section{B. 4 LOCATION}

Tables B-15 through B-19 are for the location calculations. The data in these location tables were produced from waite et al., 1986; USDA, 1984; and Texas Crop and Livestock Reporting Service, 1984a, b, c; 1985. 
Table B-2. Ingestion Pathways Input Data, Province

\begin{tabular}{|c|c|c|c|c|}
\hline Food Type & $\begin{array}{c}\text { Acres } \\
\text { Grown } \\
\text { (thousands) }\end{array}$ & $\begin{array}{l}\text { Growing } \\
\text { Period } \\
\text { (days) }\end{array}$ & $\begin{array}{l}\text { Yield } \\
\left(\mathrm{kg} / \mathrm{m}^{2}\right)\end{array}$ & $\begin{array}{c}\text { Consumption } \\
\text { Rate } \\
\text { (kg/yr/person) }\end{array}$ \\
\hline $\begin{array}{l}\text { Wheat } \\
\text { Other Grain }\end{array}$ & $\begin{array}{r}290 \\
43\end{array}$ & $\begin{array}{l}90 \\
90\end{array}$ & $\begin{array}{l}0.24 \\
0.91\end{array}$ & $\begin{array}{r}39.9 \\
5.7\end{array}$ \\
\hline Animal Product & $\begin{array}{c}\text { Kilograms } \\
\text { Produced } \\
\text { (million kg) }\end{array}$ & $\begin{array}{l}\text { Growing } \\
\text { Period } \\
\text { (days) }\end{array}$ & $\begin{array}{l}\text { Forage } \\
\left(\mathrm{kg} / \mathrm{m}^{2}\right)\end{array}$ & $\begin{array}{c}\text { Consumption } \\
\text { Rate } \\
\text { (kg/yr/person) }\end{array}$ \\
\hline $\begin{array}{l}\text { Milk } \\
\text { Beef }\end{array}$ & $\begin{array}{l}36 \\
57\end{array}$ & $\begin{array}{l}30 \\
90\end{array}$ & $\begin{array}{l}1.1 \\
1.1\end{array}$ & $\begin{array}{r}110.0 \\
95.0\end{array}$ \\
\hline
\end{tabular}

Table B-3. Affected Population by Agricultural Good, Province

\begin{tabular}{|c|c|c|c|}
\hline Food & $\begin{array}{l}\text { Method A } \\
\text { (people) }\end{array}$ & $\begin{array}{l}\text { Method B } \\
\text { (people) }\end{array}$ & $\begin{array}{l}\text { Mettiud C } \\
\text { (people) }\end{array}$ \\
\hline $\begin{array}{l}\text { Wheat } \\
\text { OLliei Grains } \\
\text { Milk } \\
\text { Beef }\end{array}$ & $\begin{array}{l}257,600 \\
257,600 \\
257,600 \\
257,600\end{array}$ & $\begin{array}{l}257,600 \\
257,600 \\
257,600 \\
257,600\end{array}$ & $\begin{array}{r}7,000,000 \\
27,000,000 \\
330,0 n n \\
600,000\end{array}$ \\
\hline
\end{tabular}


Table B-4. Individual Dose by Agricultural Good, Province

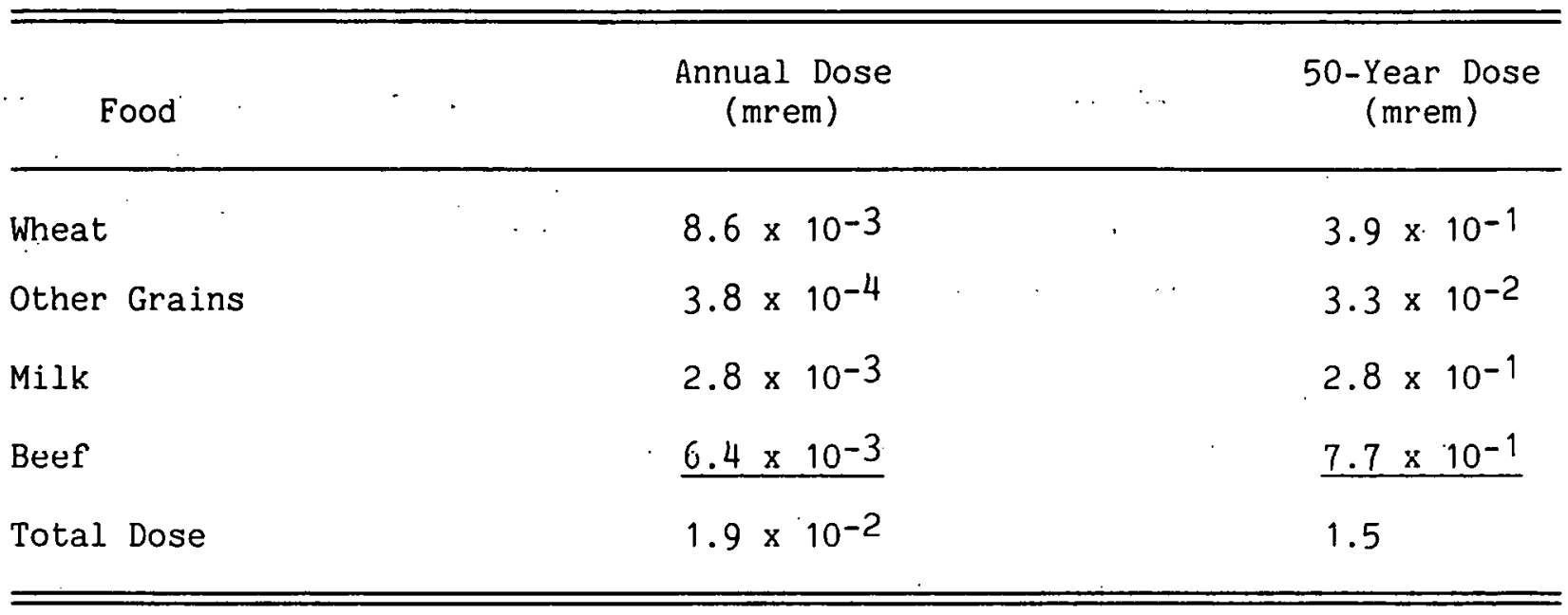

Table B-5. Population Dose by Method and Agricultural Good, Province

\begin{tabular}{|c|c|c|c|}
\hline Food & $\begin{array}{c}\text { Method A } \\
\text { (person-mrem) }\end{array}$ & $\begin{array}{c}\text { Method B } \\
\text { (person-mrem) }\end{array}$ & $\begin{array}{c}\text { Method C } \\
\text { (person-mrem) }\end{array}$ \\
\hline Annual Dose & & & \\
\hline $\begin{array}{l}\text { Wheat } \\
\text { Other Grains } \\
\text { Milk } \\
\text { Beef }\end{array}$ & $\begin{array}{r}2.2 \times 10^{3} \\
9.8 \times 10^{1} \\
7.2 \times 10^{2} \\
1.6 \times 10^{3} \\
\end{array}$ & $\begin{array}{r}2.2 \times 10^{3} \\
9.8 \times 10^{1} \\
7.2 \times 10^{2} \\
1.6 \times 10^{3} \\
\end{array}$ & $\begin{array}{r}6.0 \times 10^{4} \\
1.0 \times 10^{4} \\
9.2 \times 10^{2} \\
3.8 \times 10^{3} \\
\end{array}$ \\
\hline Total Dose & $4.9 \times 10^{3}$ & $4.9 \times 103$ & $7.5 \times 10^{4}$ \\
\hline 50-Year Dose & & & \\
\hline $\begin{array}{l}\text { Wheat } \\
\text { Other Grains } \\
\text { Milk } \\
\text { Beef }\end{array}$ & $\begin{array}{r}1.0 \times 10^{5} \\
8.5 \times 103 \\
7.2 \times 10^{4} \\
2.0 \times 10^{5} \\
\end{array}$ & $\begin{array}{l}1.0 \times 10^{5} \\
8.5 \times 10^{3} \\
7.2 \times 10^{4} \\
2.0 \times 10^{5} \\
\end{array}$ & $\begin{array}{l}2.7 \times 10^{6} \\
8.9 \times 10^{5} \\
9.2 \times 10^{4} \\
4.6 \times 10^{5} \\
\end{array}$ \\
\hline Total Dose & $3.9 \times 10^{5}$ & $3.9 \times 10^{5}$ & $4.6 \times 10^{6}$ \\
\hline
\end{tabular}


Table B-6. Ingestion Pathways Input Data, Region

\begin{tabular}{|c|c|c|c|c|}
\hline Food Type & $\begin{array}{c}\text { Acres } \\
\text { Grown } \\
\text { (thousands) }\end{array}$ & $\begin{array}{l}\text { Growing } \\
\text { Period } \\
\text { (days) }\end{array}$ & $\begin{array}{l}\text { Yield } \\
\left(\mathrm{kg} / \mathrm{m}^{2}\right)\end{array}$ & $\begin{array}{c}\text { Consumption } \\
\text { Rate } \\
\text { (kg/yr/person) }\end{array}$ \\
\hline $\begin{array}{l}\text { Wheat } \\
\text { Other Grain }\end{array}$ & $\begin{array}{r}238.0 \\
39.4\end{array}$ & $\begin{array}{l}90 \\
90\end{array}$ & $\begin{array}{l}0.24 \\
0.88\end{array}$ & $\begin{array}{r}39.9 \\
5.7\end{array}$ \\
\hline Animal Product & $\begin{array}{c}\text { Kilograms } \\
\text { Pruduced } \\
\text { (million } \mathrm{kg} \text { ) }\end{array}$ & $\begin{array}{l}\text { Crowing } \\
\text { Per'lod } \\
\text { (days) }\end{array}$ & $\begin{array}{l}\text { Forage } \\
\left(\mathrm{kg} / \mathrm{m}^{2}\right)\end{array}$ & $\begin{array}{c}\text { Consumption } \\
\text { Ráte } \\
\text { (kg/yr/person) }\end{array}$ \\
\hline $\begin{array}{l}\text { Milk } \\
\text { Beef }\end{array}$ & $\begin{array}{l}36.0 \\
54.0\end{array}$ & $\begin{array}{l}30 \\
90\end{array}$ & $\begin{array}{l}1.1 \\
1.1\end{array}$ & $\begin{array}{r}110.0 \\
95.0\end{array}$ \\
\hline
\end{tabular}

Table B-7. Affected Population by Agricultural Good, Region

\begin{tabular}{lllr}
\hline \hline \multicolumn{1}{c}{ Food } & $\begin{array}{c}\text { Method A } \\
\text { (people) }\end{array}$ & $\begin{array}{l}\text { Method B } \\
\text { (people) }\end{array}$ & $\begin{array}{r}\text { Method C } \\
\text { (people) }\end{array}$ \\
\hline & & & $5,730,000$ \\
Wheat & 300,800 & 300,800 & $24,300,000$ \\
Other Grains & 300,800 & 300,800 & 327,300 \\
Milk & 300,800 & 300,800 & 568,400 \\
Beef & 300,800 & 300,800 & \\
\hline
\end{tabular}


Table B-8. Individual Dose by Agricultural Good, Region

\begin{tabular}{lcc}
\hline \hline \multicolumn{1}{c}{ Food } & $\begin{array}{c}\text { Annual Dose } \\
\text { (mrem) }\end{array}$ & $\begin{array}{c}50-\text { Year Dose } \\
\text { (mrem) }\end{array}$ \\
\hline Wheat & $8.6 \times 10^{-3}$ & $3.9 \times 10^{-1}$ \\
Other Grains & $4.1 \times 10^{-4}$ & $3.3 \times 10^{-2}$ \\
Milk & $2.8 \times 10^{-3}$ & $2.8 \times 10^{-1}$ \\
Beef & $6.4 \times 10^{-3}$ & $\underline{7.7 \times 10^{-1}}$ \\
Total Dose & $1.9 \times 10^{-2}$ & 1.5. \\
\hline \hline
\end{tabular}

Table B-9. Population Dose by Method and Agricultural Good, Region. -

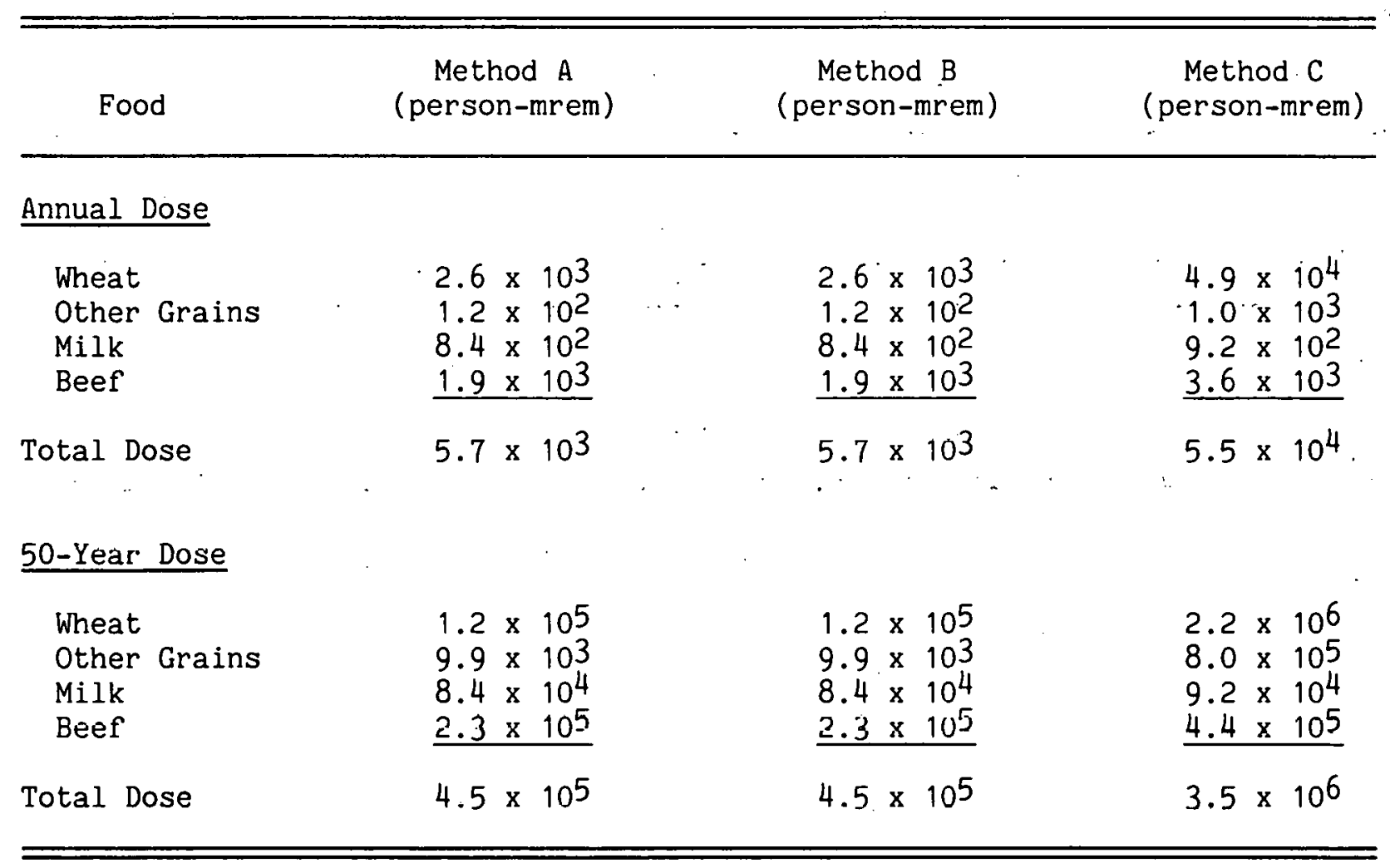


Table B-10. Ingestion Pathways Input Data, Area

\begin{tabular}{|c|c|c|c|c|}
\hline Food Type & $\begin{array}{c}\text { Acres } \\
\text { Grown } \\
\text { (thousands) }\end{array}$ & $\begin{array}{l}\text { Growing } \\
\text { Period } \\
\text { (days) }\end{array}$ & $\begin{array}{l}\text { Yield } \\
\left(\mathrm{kg} / \mathrm{m}^{2}\right)\end{array}$ & $\begin{array}{c}\text { Consumption } \\
\text { Rate } \\
\text { (kg/yr/person) }\end{array}$ \\
\hline Leafy Vegetables & 2.40 & 90 & 3.23 & 11.2 \\
\hline $\begin{array}{l}\text { Aboveground } \\
\text { Vegeldules }\end{array}$ & 17.20 & 90 & 3.78 & 79.7 \\
\hline Potatoes & 5.10 & 90 & 2.48 & 117.0 \\
\hline $\begin{array}{l}\text { Other Root } \\
\text { Vegetables }\end{array}$ & 2.53 & 90 & 2.43 & 11.7 \\
\hline Melons & 0.33 & 90 & 1.42 & 15.0 \\
\hline Wheat & 521.00 & 90 & 0.19 & 34.2 \\
\hline Other Graịn & 174.00 & 90 & 1.08 & 11.4 \\
\hline Animal Product & $\begin{array}{c}\text { Kilograms } \\
\text { Produced } \\
\text { (million kg) }\end{array}$ & $\begin{array}{l}\text { Growing } \\
\text { Period } \\
\text { (days) }\end{array}$ & $\begin{array}{l}\text { Forage } \\
\left(\mathrm{kg} / \mathrm{m}^{2}\right)\end{array}$ & $\begin{array}{c}\text { Consumption } \\
\text { Rat.e } \\
\text { (kg/yr/person) }\end{array}$ \\
\hline Milk & 17.00 & 30 & 1.1 & 110.0 \\
\hline $\operatorname{Bccf}$ & 202.00 & 90 & 1.1 & 95.0 \\
\hline
\end{tabular}


Table B-11. Affected Population by Agricultural Good, Area

\begin{tabular}{lccc}
\hline \hline \multicolumn{1}{c}{ Food } & $\begin{array}{c}\text { Method A } \\
\text { (people) }\end{array}$ & $\begin{array}{c}\text { Method B } \\
\text { (people) }\end{array}$ & $\begin{array}{c}\text { Method C } \\
\text { (people) }\end{array}$ \\
\hline $\begin{array}{l}\text { Leafy Vegetables } \\
\text { Aboveground } \\
\text { Vegetables }\end{array}$ & 128,800 & 128,800 & $2,770,000$ \\
$\begin{array}{l}\text { Potatoes } \\
\begin{array}{l}\text { Other Root } \\
\text { Vegetables }\end{array}\end{array}$ & 128,800 & 128,800 & $3,263,000$ \\
Melons & 128,800 & 128,800 & 439,000 \\
Wheat & 128,800 & 128,800 & $2,102,000$ \\
Other Grains & 128,800 & 125,000 & 125,000 \\
Milk & 128,800 & 128,800 & $11,580,000$ \\
Beef & 128,800 & 128,800 & $65,900,000$ \\
\hline \hline
\end{tabular}


Table B-12. Individual Dose by Agricultural Good, Area

\begin{tabular}{|c|c|c|}
\hline Food & $\begin{array}{l}\text { Annual. Dose } \\
\quad(\text { mrem })\end{array}$ & $\begin{array}{l}\text { 50-Year Dose } \\
\text { (mrem) }\end{array}$ \\
\hline Leafy Vegetables & $1.8 \times 10^{-3}$ & $9.3 \times 10^{-2}$ \\
\hline $\begin{array}{l}\text { Aboveground } \\
\text { Vegetables }\end{array}$ & $1.1 \times 10^{-2}$ & $6.1 \times 10^{-1}$ \\
\hline Potatoes & $3.5 \times 10^{-3}$ & $5.5 \times 10^{-1}$ \\
\hline $\begin{array}{l}\text { Other Root } \\
\text { Vegetables }\end{array}$ & $3.5 \times 10^{-4}$ & $5.5 \times 10^{-2}$ \\
\hline Melons & $6.5 \times 10^{-4}$ & $7.2 \times 10^{-2}$ \\
\hline Wheat & $9.2 \times 10^{-3}$ & $3.9 \times 10^{-1}$ \\
\hline Other Grains & $6.9 \times 10^{-4}$ & $5.7 \times 10^{-2}$ \\
\hline Milk & $2.8 \times 10^{-3}$ & $2.7 \times 10^{-1}$ \\
\hline Beef & $6.4 \times 10^{-3}$ & $7.7 \times 10^{-1}$ \\
\hline Total Dose & $3.7 \times 10^{-?}$ & 2.9 \\
\hline
\end{tabular}


Tabie B-13. Population Annual Dose by Method and Agricultural Good, Area

\begin{tabular}{lccc}
\hline \hline Food & $\begin{array}{c}\text { Method A } \\
\text { (person-mrem) }\end{array}$ & $\begin{array}{c}\text { Method B } \\
\text { (person-mrem) }\end{array}$ & $\begin{array}{c}\text { Method C } \\
\text { (person-mrem) }\end{array}$ \\
\hline $\begin{array}{l}\text { Leafy Vegetables } \\
\begin{array}{l}\text { Aboveground } \\
\text { Vegetables }\end{array}\end{array}$ & $1.4 \times 10^{3}$ & $2.3 \times 10^{2}$ & $5.0 \times 10^{3}$ \\
$\begin{array}{l}\text { Potatoes } \\
\text { Other Root } \\
\text { Vegetables }\end{array}$ & $4.5 \times 10^{2}$ & $1.4 \times 10^{3}$ & $3.6 \times 10^{4}$ \\
Melons & $4.5 \times 10^{1}$ & $4.5 \times 10^{2}$ & $1.5 \times 10^{3}$ \\
Wheat & $8.4 \times 10^{1}$ & $4.5 \times 10^{1}$ & $7.4 \times 10^{2}$ \\
Other Grains & $1.2 \times 10^{3}$ & $8.1 \times 10^{1}$ & $8.1 \times 10^{1}$ \\
Milk & $8.9 \times 10^{1}$ & $1.2 \times 10^{3}$ & $1.1 \times 10^{5}$ \\
Beef & $3.6 \times 10^{2}$ & $8.9 \times 10^{1}$ & $4.5 \times 10^{4}$ \\
Total Dose & $\underline{8.2 \times 10^{2}}$ & $3.6 \times 10^{2}$ & $4.3 \times 10^{2}$ \\
\hline \hline & $4.8 \times 10^{3}$ & $8.2 \times 10^{2}$ & $1.4 \times 10^{4}$ \\
\hline
\end{tabular}


Table B-14. Population 50-Year Dose by Method and Agricultural Good, Area

\begin{tabular}{|c|c|c|c|}
\hline Food & $\begin{array}{c}\text { Method A } \\
\text { (person-mrem) }\end{array}$ & $\begin{array}{c}\text { Method B } \\
\text { (person-mrem) }\end{array}$ & $\begin{array}{c}\text { Method C } \\
\text { (person-mrem) }\end{array}$ \\
\hline Leafy Vegetables & $1.2 \times 10^{4}$ & $1.2 \times 10^{4}$ & $2.6 \times 10^{5}$ \\
\hline $\begin{array}{l}\text { Aboveground } \\
\text { Vegetables }\end{array}$ & $7.9 \times 10^{4}$ & $7.9 \times 10^{4}$ & $2.0 \times 10^{6}$ \\
\hline Potatoes & $7.1 \times 10^{4}$ & $7.1 \times 10^{4}$ & $2.4 \times 10^{5}$ \\
\hline $\begin{array}{l}\text { Other Root } \\
\text { Vegetables }\end{array}$ & $7.1 \times 10^{3}$ & $7.1 \times 10^{3}$ & $1.2 \times .10^{5}$ \\
\hline Melons & $9.3 \times 10^{3}$ & $9.0 \times 10^{3}$ & $9.0 \times 10^{3}$ \\
\hline Wheat & $5.0 \times 10^{4}$ & $5.0 \times 10^{4}$ & $4.5 \times 10^{6}$ \\
\hline Other Grains & $7.3 \times 10^{3}$ & $7.3 \times 10^{3}$ & $3.8 \times 10^{6}$ \\
\hline Milk & $3.5 \times 10^{4}$ & $3.5 \times 10^{4}$ & $4.2 \times 10^{4}$ \\
\hline Beef & $9.9 \times 10^{4}$ & $9.9 \times 10^{4}$ & $1.6 \times 10^{6}$ \\
\hline Total Dose & $3.7 \times 10^{5}$ & $3.7 \times 10^{5}$ & $1.3 \times 10^{7}$ \\
\hline
\end{tabular}


Table B-15. Ingestion Pathways Input Data, Location

\begin{tabular}{|c|c|c|c|c|}
\hline Food Type & $\begin{array}{c}\text { Acres } \\
\text { Grown } \\
\text { (thousands) }\end{array}$ & $\begin{array}{l}\text { Growing } \\
\text { Period } \\
\text { (days) }\end{array}$ & $\begin{array}{c}\text { Yield } \\
\left(\mathrm{kg} / \mathrm{m}^{2}\right)\end{array}$ & $\begin{array}{c}\text { Consumption } \\
\text { Rate } \\
\text { (kg/yr/person) }\end{array}$ \\
\hline Leafy Vegetables & 0.47 & 90 & 2.6 & 14.5 \\
\hline $\begin{array}{l}\text { Aboveground } \\
\text { Vegetables }\end{array}$ & 0.34 & 90 & 1.0 & 11.4 \\
\hline Potatoes & 2.91 & 90 & 2.4 & 24.6 \\
\hline $\begin{array}{l}\text { Other Root } \\
\text { Vegetables }\end{array}$ & 2.30 & 90 & 2.5 & 9.9 \\
\hline Melons & 0.98 & 90 & 1.3 & 7.8 \\
\hline Wheat & 270.90 & 90 & 0.1 & 54.0 \\
\hline Other Grain & 22.10 & 90 & 0.3 & 4.0 \\
\hline Animal Product & $\begin{array}{c}\text { Kilograms } \\
\text { Produced } \\
\text { (million kg) }\end{array}$ & $\begin{array}{l}\text { Srowing } \\
\text { Period } \\
\text { (days) }\end{array}$ & $\begin{array}{l}\text { Forage } \\
\left(\mathrm{kg} / \mathrm{m}^{2}\right)\end{array}$ & $\begin{array}{c}\text { Consumption } \\
\text { Rate } \\
\text { (kg/yr/person) }\end{array}$ \\
\hline Milk & 22.00 & 30 & 1.1 & 111.4 \\
\hline Beef & 193.20 & 90 & 1.1 & 35.2 \\
\hline Pork & 5.40 & 90 & 1.1 & 28.9 \\
\hline Poultry & $0.31(a)$ & 90 & 1.1 & 28.6 \\
\hline
\end{tabular}

(a) Calculated value, based on 5 percent criteria. 
Table B-16. Affected Population by Agricultural Good, Location

\begin{tabular}{lllr}
\hline \hline \multicolumn{1}{c}{ Food } & $\begin{array}{c}\text { Method A } \\
\text { (people) }\end{array}$ & $\begin{array}{c}\text { Method B } \\
\text { (people) }\end{array}$ & $\begin{array}{c}\text { Method C } \\
\text { (people) }\end{array}$ \\
\hline $\begin{array}{l}\text { Leafy Vegetables } \\
\text { Aboveground } \\
\text { Vegetables }\end{array}$ & 217,000 & 217,000 & 343,000 \\
Potatoes & 217,000 & 125,100 & 125,100 \\
Other Root & 217,000 & 217,000 & $1,142,600$ \\
Vegetables & 217,000 & 217,000 & $2,344,400$ \\
Melons & 217,000 & 217,000 & 647,800 \\
Wheat & 217,000 & 217,000 & $1,881,300$ \\
Other Grains & 217,000 & 217,000 & $7,320,600$ \\
Milk & 217,000 & 197,500 & 197,500 \\
Beef & 217,000 & 217,000 & 10,900 \\
Pork & 217,000 & 187,000 & $18,900(\mathrm{a})$ \\
Poultry & 217,000 & & 187,000 \\
\hline \hline
\end{tabular}

(a) Calculated value, based on 5 percent criteria. 
Table B-17. Individual Dose by Agricultural Good; Location

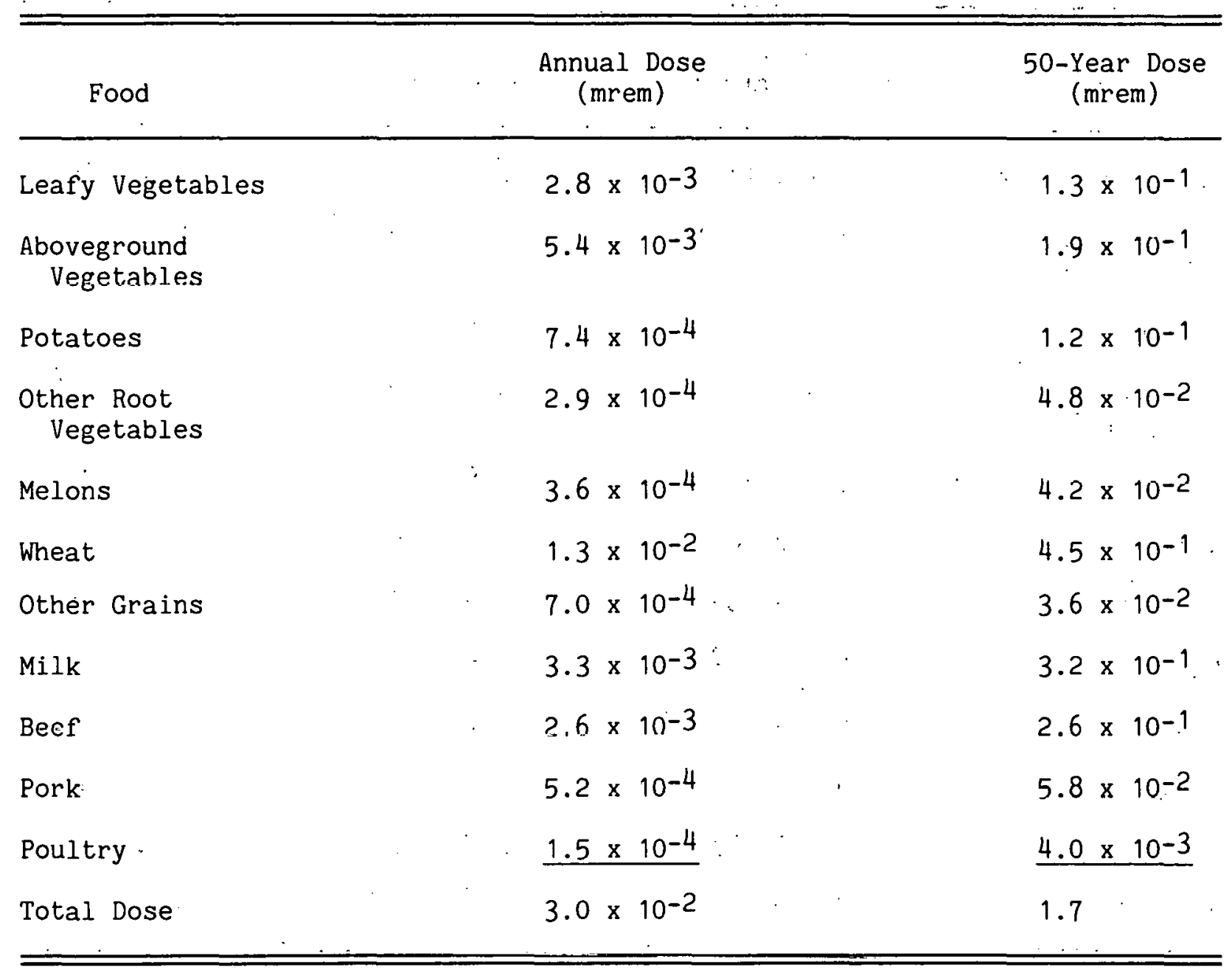


Table B-18. Population Annual Dose by Method and Agricultural Good, Location

\begin{tabular}{|c|c|c|c|}
\hline Food & $\begin{array}{c}\text { Method A } \\
\text { (person-mrem) }\end{array}$ & $\begin{array}{c}\text { Method B } \\
\text { (person-mrem) }\end{array}$ & $\begin{array}{c}\text { Method C } \\
\text { (person-mrem) }\end{array}$ \\
\hline Leafy Vegetables & $6.1 \times 10^{2}$ & $6.1 \times 10^{2}$ & $9.6 \times 10^{2}$ \\
\hline $\begin{array}{l}\text { Aboveground } \\
\text { Vegetables }\end{array}$ & $1.2 \times 10^{3}$ & $6.8 \times 10^{2}$ & $6.8 \times 10^{2}$ \\
\hline Potatoes & $1.6 \times 10^{2}$ & $1.6 \times 10^{2}$ & $8.5 \times 10^{2}$ \\
\hline $\begin{array}{l}\text { Other Root } \\
\text { Vegetables }\end{array}$ & $6.3 \times 10^{1}$ & $6.3 \times 10^{1}$ & $6.8 \times 10^{2}$ \\
\hline Melons & $7.8 \times 10^{1}$ & $7.8 \times 10^{1}$ & $2.3 \times 10^{2}$ \\
\hline Wheat & $2.8 \times 10^{3}$ & $2.8 \times 10^{3}$ & $2.4 \times 10^{4}$ \\
\hline Other Grains & $1.5 \times 10^{2}$ & $1.5 \times 10^{2}$ & $5.1 \times 10^{3}$ \\
\hline Milk & $7.2 \times 10^{2}$ & $6.5 \times 10^{2}$ & $6.5 \times 10^{2}$ \\
\hline Beef & $5.6 \times 10^{2}$ & $5.6 \times 10^{2}$ & $1.8 \times 10^{4}$ \\
\hline roink & $1.1 \times 10^{2}$ & $9.7 \times 10^{1}$ & $9.7 \times 10^{1}$ \\
\hline Poultry & $3.3 \times 10^{5}$ & 1.6 & 1.6 \\
\hline Total Dose & $6.5 \times 10^{3}$ & $5.8 \times 10^{3}$ & $5.1 \times 10^{4}$ \\
\hline
\end{tabular}


Table B-19. Population 50-Year Dose by Method and Agricultural Good, Location

\begin{tabular}{|c|c|c|c|}
\hline Food & $\begin{array}{c}\text { Method A } \\
\text { (person-mrem) }\end{array}$ & $\begin{array}{c}\text { Method B } \\
\text { (person-mrem) }\end{array}$ & $\begin{array}{c}\text { Method C } \\
\text { (person-mrem) }\end{array}$ \\
\hline Leafy Vegetables & $2.8 \times 10^{4}$ & $2.8 \times 10^{4}$ & $4.5 \times 10^{4}$ \\
\hline $\begin{array}{l}\text { Aboveground } \\
\text { Vegetables }\end{array}$ & $1.1 \times 10^{4}$ & $2.4 \times 10^{4}$ & $2.4 \times 10^{4}$ \\
\hline Potatoes & $2.6 \times 10^{4}$ & $2.6 \times 10^{4}$ & $1.4 \times 10^{5}$ \\
\hline $\begin{array}{l}\text { Other Root } \\
\text { Vegetables }\end{array}$ & $1.0 \times 10^{4}$ & $1.0 \times 10^{4}$ & $1.1 \times 10^{5}$ \\
\hline Melons & $9.1 \times 10^{3}$ & $9.1 \times 10^{3}$ & $2.7 \times 10^{4}$ \\
\hline Wheat & $9.8 \times 10^{4 /}$ & $9.8 \times 10^{4}$ & $8.5 \times 10^{5}$ \\
\hline Other Grains & $7.8 \times 10^{3}$ & $7.8 \times 10^{3}$ & $2.6 \times 10^{5}$ \\
\hline Milk & $6.9 \times 10^{4}$ & $6.3 \times 10^{4}$ & $6.3 \times 10^{4}$ \\
\hline Beef & $5.6 \times 10^{4}$ & $5.6 \times 10^{4}$ & $1.8 \times 10^{6}$ \\
\hline Pork & $1.3 \times 10^{4}$ & $1.1 \times 10^{4}$ & $1.1 \times 10^{4}$ \\
\hline Poultry & $8.7 \times 10^{2}$ & $4.4 \times 10^{1}$ & $4.4 \times 10^{1}$ \\
\hline Total Dose & $3.7 \times 10^{5}$ & $3.3 \times 10^{5}$ & $3.3 \times 10^{6}$ \\
\hline
\end{tabular}




\section{THIS PAGE \\ WAS INTENTIONALLY \\ LEFT BLANK}




\section{DISTRIBUTION LIST}

AEROSPACE CORP

KENNETH W. STEPHENS

ALABAMA STATE GEOLOGICAL SURVEY THORNTON L. NEATHERY

AMERICAN ROCK WRITING RESEARCH JOHN NOXON

APPLIED RESEARCH ASSOCIATES STEVEN WOOLFOLK

ARGONNE NATIONAL LABORATORY JOHN DITMARS

DORLAND E. EDGAR

DOUGLAS F. HAMBLEY

WYMAN HARRISON

TOM KASSNER

MARTIN I. STEINDLER

ARIZONA NUCLEAR POWER PROJECT HENRY W. RILEY, JR.

ARTHUR D. LITTLE INC CHARLES R. HADLOCK

ATKINS RESEARCH \& DEVELOPMENT-UNITED KINGDOM

T. W. BROYD

ATOMIC ENERGY CONSULTANTS

UUNALU G. ANÚERSÓN

ATOMIC ENERGY CONTROL BOARD-CANADA KEN SHULTZ

ATOMIC ENERGY OF CANADA LTD

T. CHAN

SIEGRUN MEYER

ATOMIC ENERGY RESEARCH ESTABLISHMENT-

UNITED KINGDOM

D. P. HODGKINSON

BATTELLE MEMORIAL INSTITUTE

IOHN T. MCGINNIS

JEFFREY L. MEANS

NEIL E. MILLER

STEPHEN NICOLOSI

RICHARD M. WINAR

BCM CONVERSE INC ROBERT J. MAINUEL

BECHTEL NATIONAL INC LESLIE J. JARDINE GERALD L. PALAU

BERKELEY GEOSCIENCES/HYDROTECHNIQUE

ASSOCIATES BRIAN KANEHIRO

BLACK \& VEATCH M. JOHN ROBINSON

BOWOOIN COLLEGE EDWARD P. LAINE

BRENK SYSTEMPLANUNG-W. GERMANY H. D. BRENK

BROOKHAVEN NATIONAL LABORATORY M. S. DAVIS

RALPH R. FULLWOOD

PETER SOO

HELEN TODOSOW (2)

BROOME COMMUNITY COLLECE BRUCE OLDFIELD

BROWN UNIVERSITY MiCHELE BURKE

BUNDESANSTALT FUR GEOWISSENSCHAFTEN UND ROHSTOFFE-W. GERMANY MICHALL LANGER. HELMUT VENZLAFF

BUREAU DE RECHERCHES GEOLOGIQUES ET

MINIERES-FRANCE

BERNARD FEUGA

PIERRE F. PEALIDECERF

CALIFORNIA DEPT OP COINSERVATION PERRY AMIMITO
CANVIRO CONSULTANTS

DOUG METCALFE

CAPITAL UNIVERSITY

VICTOR M. SHOWALTER

CAYUGA LAKE CONSERVATION ASSOCIATION INC

D. S. KIEFER

CENTER FOR ENVIRONMENTAL HEALTH CAMERON MCDONALD VOWELL

CENTER FOR ENVIRONMENTAL INFORMATION INC FREDERICK W. STOSS

CENTER FOR INTERDISCIPLINARY STUDIES DAVID M. ARMSTRONG

CER CORP

ELLA JACKSON

CITIZENS AGAINST NUCLEAR DISPOSAL INC STANLEY D. FLINTT

CLARK UNIVERSITY JEANNE X. KASPERSON

CLEVELAND ELECTRIC ILLUMINATING COMPANY

GAYLE M. HUSTON

COLBY COLLECE BRUCE F. RUEGER

COLORADO GEOLOGIC INC MIKE E. BRAZIE

COLORADO GEOLOGICAL SURVEY JOHN W. ROLO

COLORADO STATE UNIVERSITY FRANK A. KULACKI

COLUMBIA UNIVERSITY M. ASHRAF MAHTAB

CONGRESSIONAL INFORMATION SERVICE PHYLLIS KLUN

CONNECTICUT STATE DEPT OF

ENVIRONMENTAL PROTECTION KEVIN MCCARTHY

COPPE/UFR] LUIZ OLIVEIRA

CORSTAR RESEARCH INC DOUGLAS K. VOGT

COUNCIL OF ENERGY RESOURCE TRIBES WYATT M. ROGERS, IR:

DAMES \& MOORE

RON KEAR

ROBERT W. KUPP

CHARLES R. LEWIS

DANIEL B. STEPHEINS AND ASSOCIATES ROBERT C. KNOWLTON, JR. ..

DEPT OF THE NAVY GENNARO MELLIS

DESERET NEWS JOSEPH BAUMAN

DEUTSCHE GESELLSCHAFT ZUM BAU UND

BETRIEB VON ENDLAGERN GERNOT GRUBLER

DISPOSAL SAFETY INC BENIAMIN ROSS

DUNN GEOSCIENCE CORP WILLIAM E. CUTCLIFFE FRANCIS S. KENDORSKI

E.I. DU PONT DE NEMOURS \& CO A. B. MILLER

E.R. JOHNSON ASSOCIATES INC E. R. JOHNSON C. L. JOHNSON

EAL. CORP I.FON I.FVFNTHAL

EARTII SCIENCE AND ENGINECRING INC LOU BLANCK
EARTH SCIENCES CONSULTANTS INC HARRY L. CROUSE

EARTH TECHNOLOGY CORPORATION KHOSROW BAKHTAR

EAST TENNESSEE STATE UNIVERSITY ALBERT F. IGLAR

EBASCO SERVICES INC KATHLEEN E. L. HOWE GARRY MAURATH

ECOLE DES MINES DE PARIS GHISLAIN DEMARSILY

ECOLOGY \& ENVIRONMENT INC MICHAEL BENNER

ELECTRIC POWER RESEARCH INSTITUTE CHAIM BRAUN

ELEKTRIZITAETS-GES. LAUFENBURG H. N. PATAK

ELSAM-DENMARK ARNE PEDERSEN

ENERGY RESEARCH GROUP INC MARC GOLDSMITH

ENGINEERINC ANALYSIS INC WILLIAM MULLEN

ENGINEERS INTERNATIONAL INC ROBERT A. CUMMINCS. LIBRARY MADAN M. SINGH

ENVIRON SCIENCE \& ENGINEERING INC RANDY L. SCHULZE

ENVIRONMENTAL DEFENSE FUND JAMES B. MARTIN

ENVIRONMENTAL POLICY INSTITUTE DAVID M. BERRICK

EXXON COMPANY, USA MICHAEL FARRELL

EXXON NUCLEAR COMPANY INC GERALD L. RITTER

FEDERAL INSTITUTE FOR GEOSCIENCES AND NATURAL RESOURCES HANIS K. NIPP

FENIX \& SCISSON INC CHARIENE U. SPARKMAN

FERRIS STATE COLLECE MICHAEL E. ELLS

FINNISH CENTRE FOR RADIATION AND $:$,

NUCLEAR SAFETY KAI JAKOBSSON

FLORIDA INSTITUTE OF TECHNOLOGY JOSEPH A. ATGGELO, IR.

FLORIDA STATE' UNIVERSITY JOSFPH F. DONOGHUE

FLUID PROCESSES RESEARCH GROUP BRITISH

GEOLOGICAL SURVEY NEIL A. C.HAPMAN

FLUOR TECHNOLOGY INC JAMES K. CLARK, JR.

FLUOR TECHNOLOGY INC-ADVANCED

TECHNOIOSYY DIVISION

FOUR CORNERS COMMUNITY MENTAL HEALTH

CENTER DOB GRLCPSBLRC

FUTURE RESOURCES ASSOCIATES INC ROBERT I.. BUDNITZ

GA TECHNOLOGIES INC MICHAEL STAMATELATOS

GARTNER LEE LTD ROBERT E. J. LEECH

GEOLOGICAL SURVEY OF CANADA IEFFREY HUME

GEOLOGICAL SURVEY OF NORWAY SIGURD HUSEBY 
GEOMIN INC

$$
\text { J. A. MACHADO }
$$

GEORGIA INSTITUTE OF TECHNOLOGY

GEOFFREY C. [ICHHOLZ

ALFRED SCHNEIDER

GEOSYSTEMS RESEARCH INC RANDY L. BASSETT

GEOTRANS INC IAMES MERCER

GOLDER ASSOCIATES MELISSA MATSON

FRANK S. SHURI

J. W. VOSS

GOLDER ASSOCIATES-CANADA CLEMENT M. K. YUEN

GOVERNMENT DOCUMENTS DEPT-UNIVERSITY LIBRARY

GRAM, INC KRISHAN K. WAHI

GRAND COUNTY HIGH SCHOOL LIBRARY

GRAND COUNTY PUBLIC LIBRARY

GULF INTERSTATE ENGINEERINC THOMAS J. HILL

H\& K TECHNICAL ASSUCIAIIES INE WILLIAM R. RHYNE

H. LAWROSKI \& ASSOCIATES P.A. HARRY LAWROSÉKi

H-TECH LABORATORIES INC BRUCE HARTENBAUM

HANFORD OVERSIGHT COMMITTEE LARRY CALDWCLL

HARVARD UNIVERSITY CHARLES W. BURNHAM DADE W. MOELLER RAYMOND SIEVER

HARZA ENGINEERING COMPANY PETER CONROY

HEREFORD NUCLEAR WASTE INFORMATION OFFICE CAROLYN JOHNSON

HIGH PLAINS WATER DISTRICT DON MCREYNOLDS A. WAYNE WYATT

HITACHI WORKS, HITACHI LTD MAK.OTO K.IK.LIEHI

HOUGH-NORWOOD HEALTH CARE CENTER GEORGE H. BROWN, M.D.

HUMBOLDT STATE UNIVERSITY JOHN LONGSHORE

ILLINOIS DEPT OF NUCLEAR SAFETY JOHN CODPER TERRY R. LASII

ILLINOIS STATE GEOLOGICAL SURVEY MORRIS W. LEIGHTON

INDIANA UNIVERSITY CHARLES J. VITALIANO

INSTITUT FUR TIEFLAGERUNG-W. GERMANY WERNT BREWITZ E. R. SOLTER

INSTITUTE FOR CHEMICAL TECHNOLOGY-W. GERMANY REINHARD ODOJ

INSTITUTE OF PLASMA PHYSICS H. AMANO

INSTITUTO DE INVESTIGACIONES FISICOQUIMICAS TEORICAS Y APLICADAS I. R. VILCHE

INTER/FACE ASSOCIATES INC RON GINGERICH

INTERA TECHNOLOGIES INC JAMES E. CAMPBELL JOHN F. PICKENS MARK REEVES
INTERNATIONAL ENGINEERING COMPANY INC MAX ZASLAWSKY

INTERNATIONAL GROUND WATER MODELING CENTER

PAUL K. M. VAN DER HEIJDE

INTERNATIONAL RESEARCH AND EVALUATION R. DANFORD

IOWA STATE COMMERCE COMMISSION

IOWA STATE UNIVERSITY BERNARD I. SPINRAD

ISTITUTO SPERIMENTALE MODELLI E STRUTTURE

S.P.A.-ITALY FERRUCCIO GERA

IT COKP

PETER C. KELSALL

ITASCA CONSULTING GROUP INC CHARLES FAIRHURST ROCER HART

J. L. MAGRUDER \& ASSOCIATES J. L. MAGRUDER

J.F.T. AGAPITO \& ASSOCIATES INC MICHAEL P. HARDY

JACOBY \& COMPANY CHARLES H. JACOBY

JAMES MADISON UNIVERSITY STEPHEN B. HARPER

JGC CORPORATION-IAPAN MASAHIKO MAKINO

IK RESEARCH ASSOCIATES INC CINDY CHIFOS

JOHNS HOPKINS UNIVERSITY JARED L. COHON

IOINT STUDY COMMITTEE ON ENERGY T. W. EDWARDS, JR.

IONES COUNTY JUNIOR COLLEGE LIBRARY

JUPITER ASSOCIATES INC. CLYDE JUPITER

KAISER ENGINEERS INC BEVERLY S. AUSMUS

KALAMAZOO COLLEGE RALPH M. DEAL

KANSAS DEPT OF HEALTH ANU ENVIRUNMENI GERALD W. ALLEN

KELLER WREATH ASSOCIATES FRANK WRFATH

KERNFORSCHUNCSLENIKUM KARLSRUHE

GMBB̈H-WW. CEERMANY K. D. CLOSS

R. KOESTER

KETTERING FOUNDATION ESTUS SMITH

KIHN ASSOCINTES HARRY KIHN

KILLCORES INC CHARLES KILLGORE

KIMBERLY MECHANICAL CONSULTANTS KENNETH CROMWELL

KLM ENGINEERING INC B. GEORGE KNIAZEWYCZ

KUTA RADIO

KUTV-TV ROBERT LOY

LAKE SUPERIOR REGION RADIOACTIVE WASTE PROJECT C. DIXON

LAWRENCE BERKELEY LABORATORY EUGENE P. BINNALL NORMAN M. EDELSTEIN I. WANG

LAWRENCE LIVERMORE NATIONAL

LABORATORY THOMAS E. MCKONE WILLIAM J. OCONNELL
LAWRENCE D. RAMSPOTT (2) DAVID B. SLEMMONS

TECHNICAL INFORMATION DEPARTMENT WASTE PACKAGE TASK LIBRARY

LEAGUE OPPOSING SITE SELECTION LINDA S. TAYLOR

LIBRARY OF MICHIGAN RICHARD J. HATHAWAY

LOCKHEED ENGINEERING \& MANAGEMENT COMPANY STEVE NACHT

LOS ALAMOS NATIONAL LABORATORY ERNEST A. BRYANT

B. CROWE

C. W. MYERS

DONALD T. OAKLEY

LOUISIANA DEPT OF ENVIRONMENTAL

QUALITY

L. HALL BOHLINGER JAMES I. FRILOUX

LOUISIANA GEOLOGICAL SURVEY SYED HAQUE

LOUISIANA STATE UNIVERSITY JCRTRCY' S. HAAPOR

LOUISIANA TECHNICAL UNIVERSITY LIBRARY

R. H. IHOMYSUN

LOWENBERG ASSOCIATES HOMER LOWENBERG

LUMMUS CREST INC MARION DABROWSKI

LYLE FRANCIS MININC COMPANY LYLE FRANCIS

M.J. OCONNOR \& ASSOCIATES LTD M. J. OCONNOR

MARTIN MARIETTA CATHY S. FORE

MARYLAND DEPT OF HEALTH \& MENTAL HYGIENE MAX EISENBERG

MAŚSACHHUSÉTTSS INSTITUTE OF TECHNOLOCY RICHAKD K. LESTER MARSHA LEVINE DANIEL METLAY

MCDFRMIITT INTFẼNATIOINAI KAREN L. FURLOW

MCMASTER UNIVERSITY-CANAUA L. W. SHEMILT

MELLEN GEOLOGICAL ASSOCIATES INC FREDERIC F. MELLEN

MEMBERS OF THE GENERAL PUBLIC

ROGER H. BROOKS

LAWRENCE CHASE, PH.D.

TOM \& SIJSAN CI.AWSON ROBERT DEADMAN GERALD A. DRAKE, M.D. CARL. EISEMANN (2) WARREN EISTER JERRY L. ELLIS GERALDINE A. FERRARO CARL A. GIESE

OSWALD H. GREAGER KENNETH GUSCOTT

A. M. HALE MICHAEL T. HARRIS TALMADGE HEFLIN JOSEPH M. HENNIGAN B. JEANINE HULL DOROTHY HUSEBY KENNETH S. JOHNSON THOMAS H. LANGEVIN LINDA LEHMAN MICHAEL A. LETENDRE 
JOSEPH A. LIEBERMAN

STEVEN J. MAHERAS

DUANE MATLOCK

MAX MCDOWELL

A. ALAN MOCHISSI

TONY MORCAN

DENNIS MRAZ

F. J. PEARSON, JR.

CAROLINE PETTI

L. M. PIERSON

HOWARD PINCUS

PETER J. SABATINI, JR.

ZUBAIR SALEEM

OWEN SEVERANCE

LEWIS K. SHUMWAY

FRANK STEINBRIINN

M. J. SZULINSKI

EBIMO D. UMBU

A. E. WASSERBACH

SUSAN D. WILTSHIRE

MERRIMAN AND BARBER CONSULTING

ENCINEERS INC

GENE R. BARBER

MICHAEL BAKER, JR. INC

C. J. TOUHILL

MICHIGAN DEPT OF PUBLIC HEALTH ARTHUR W. BLOOMER

MICHIGAN DISTRICT HEALTH DEPT NO. 4 EDGAR KREFT

MIC.HICIAN ENVIRONMENTAL COUNCIL

MICHICAN PUBLIC SERVICE COMMISSION RON CALLEN

MICHIGAN UNITED CONSERVATION CLUBS WAYNE SCHMIDT

MIDDLETON LIBRARY

M. S. BOLNER

MINDEN NUCLEAR WASTE INFORMATION

OFFICE

SHIRLEY JOHNSON

MINE CRAFT INC NORBERT PAAS

MINNESOTA DEPT OF HEALTH

ALIUE T. DOLEZAL-HEINIVICAIN

MINNESOTA GEOLOGICAL SURVEY PRISCILLA C. GREW

MINNESOTA STATE PLANNING AGENCY BILL CLAUSEN

MISSISSIPPI ATTORNEY GENERALS OFFICE LISA A. SPRUILL

MISSISSIPPI BUREAU OF GEOLOGY MICHAEL B. E. BOGRAD

MISSISSIPPI DEPT OF ENERCY AND

TRANSPORTATION

DON CIIRISTY

MISSISSIPPI DEPT OF NATURAL RESOURCES

ALVIN R. BICKER, JR.

CHARLES L. BLALOCK

MISSISSIPPI DEPT OF WILDLIFE CONSERVATION KENNETH L. GORDON

MISSISSIPPI MINERAL RESOURCES INSTITUTE

MISSISSIPPI STATE DEPT OF HEALTH EDDIE S. FUENTE

MISSISSIPPI STATE UNIVERSITY

JUHN E. MYLLR̈UIE

MITRE CORP

LESTER A. ETTLINGER

MOAB NUCLEAR WASTE INFORMATION OFFICE MICHAELENE PENDLETON (2)

MORRISON-KNUDSEN COMPANY INC BILL GALE

NAGRA-SWITZERLAND

CHARLES MCCOMBIE
NATIONAL ACADEMY OF SCIENCES

JOHN T. HOLLOWAY

NATIONAL AERONAUTICS AND SPACE

ADMINISTRATION-JOHNSON SPACE CENTER MICHAEL R. HELFERT

NATIONAL ATOMIC MUSEUM LORETTA HELLINC

NATIONAL BOARD FOR SPENT NUCLEAR FUEL, KARNBRANSLENAMDEN-SWEDEN NILS RYDELL

NATIONAL GROUND WATER INFORMATION CENTER JANET BIX

NATIONAL PARK SERVICE CECIL D. LEWIS, JR. I.. L. MINTZMEYER PETER L. PARRY

NATIONAL PARKS \& CONSERVATION

ASSOCIATION TERRI MARTIN

NATIONAL SCIENCE FOUNDATION ROYAL E. ROSTENBACH

NATIONAL STORAGE TANK PROCRAM CARL E. SCHUBERT

NATIONAL WATER WELL ASSOCIATION VALERIE ORR

NEW MEXICO ENVIRONMENTAL EVALUATION GROUP ROBERT H. NEILL

NEW MEXICO INSTITUTE OF MINING AND TECHNOLOGY JOHN L. WILSON

NEW YORK DEPT OF HEALTH DAVID AXELROD, M.D.

NEW YORK ENERGY RESEARCH \&

DEVELOPMENT AUTHORITY JOHN P. SPATH (8)

NEW YORK STATE ASŚEMBLY WILLIAM B. HOYT

NEW YORK STATE ATTORNEY GENERALS OFFICE PETER SKINNER

NEW YORK STATE DEPT OF ENVIRONMENTAL CONSERVATION PAUL MERGES

NEW YORK STATE ENVIRONMENTAL, FACILITIES CORP

PICKETT T. SIMPSON

NEW YORK STATE HEALTH DEPT JOHN MATUSZEK

NEW YORK STATE PUBLIC SERVICE COMMISSION FRED HAAC

NEYER, TISEO, \& HINDO LTD KAL R. HINDO

NIAGARA MOHAWK POWER CORP GERALD K. RHODE

NORTH CAROLINA STATE UNIVERSITY M. KIMBERLEY

NORTHWESTERN UNIVERSITY BERNARD I. WOOD

NUCLLAR ASSURANCE COIP IOHN V. HOUSTON

NUGCI.FAR DEVEI.OPMENT DIVISION YUNC M. YAKK

NUCLEAR SAFETY RESEARCH ASSOCIATION HIDETAKA ISHIKAWA

NUCLEAR WASTE CONSULTANTS ADRIAN BROWN

NUCLEAR WASTE INFORMATION CENTER

MISSISSIPPI STATE LAW LIBRARY IUDITH HUTSON

NUCLEAR WASTE WATCHERS HELEN LEIARTTE
NUS CORP

W. G. BELTER

RODNEY J. DAVIS

DOUGLAS D. ORVIS

NWT CORP

W. L. PEARL

OAK RIDGE NATIONAL LABORATORY

I. O. BLOMEKE

ALLEN C. CROFF

DAVID C. KOCHER

E. M. OBLOW

FRANCOIS G. PIN

ELLEN D. SMITH

SUSAN K. WHATLEY

OHIO DEPT OF HEALTH

ROBERT M. QUILLIN

OHIO ENVIRONMENTAL PROTECTION AGENCY HAROLD W. KOHN

OKLAHOMA STATE DEPT OF HEALTH R. L. CRAIC

ONR DETACHMENT DAVID EPP

ONTARIO HYDRO-CANADA

R. W. BARNES

I. A. CHADHA

K. A. CORNELL

C. F. LEE

ONTARIO RESEARCH FOUNDATION-CANADA LYDIA M. LUCKEVICH

ORANGE COUNTY COMMUNITY COLLEGE LAWRENCE E. OBRIEN

ORECON UEPT OF ENERGY DAVID A. STEWART-SMITH

ORECON STATE UNIVERSITY JOHN C. RINGLE

ORGANIZATION FOR ECONOMIC

COOPERATION AND DEVELOPMENT-FRANCE STEFAN C. CARLYLE

PACIFIC NORTHWEST LABORATORY

DON J. BRADLEY

H. C. BURKHOLDER

T. D. CHIKALLA

CHARLES R. COLE

WILLIAM CONBERE

FLOYD N. HODGES

J. H. JARRETT

MAX R. KREITER

J. M. LATKOVICH

J. E. MENDEL

J. M. RUSIN

R. JEFF SERNE

ABRAHAM E. VAN LUIK

PARSONS BRINCKERHOFF QUADE \& DOUGLAS INC

T. R. KUESEL

ROBERT PRIETO

PARSONS BRINCKERHOFF/PB-KBB KAROLYN KENNEDY

PARSONS-REDPATH

DAVID C. NORTHCUTT

KRISI IPAA SIIRIYASTAVA

GLEN A. STAFFORD

PR-KBB INC

JUUIIH L. HACKNEY

PENNSYLVANIA STATE UNIVERSITY WILLIAM B. WHITE

PHYSIKALISCH-TECHNISCHE BUNDESANSTALTW. GERMANY PETER BRENNECKE

POBERESKIN INC MEYER POBERESKIN 
POTASH CORPORATION OF SASKATCHEWANCANADA

GRAEME G. STRATHDEE

POWER REACTOR AND NUCLEAR FUEL

DEVELOPMENT CORP-JAPAN

PRINCIPLED NEGOTIATIONS ARNIE WIGHT

PUBLIC SERVICE ELECTRIC \& GAS IOHN J. MOLNER

RADIAN CORP RICHARD STRICKERT

RADIOACTIVE WASTE CAMPAIGN MARVIN RESNIKOFF

RAYMOND KAISER ENGINEERS W. J. DODSON

RE/SPEC INC GARY D. CALLAHAN PAUL. F. GNIRK

REDCO INC WILLIAM E. SHAFER

RENWICK P. DEVILLE AND ASSOC INC KFNWICK P. DOFVIIIF

RICHTON NUCLEAR WASTE INFORMATION OFFICE BOB FREEMAN

RISO NATIONAL LABORATORY-DENMARK LARS CARLSTEN

ROCKWELL HANFORD OPERATIONS RONALD C. ARNETT

JAMES L. ASH HARRY BABAD G. S. BARNEY BRAD ERLANDSON SALLY C. FITZPATRICK KUNSOO KIM

ROCKWELL INTERNATIONAL ENERGY SYSTEMS GROUP HARRY PEARLMAN

ROGERS \& ASSOCIATES ENGINEERING CORP ARTHUR A. SUTHERLAND ROBERT E. WILEMS

ROY F. WESTON INC E. F. BENZ MICHAEL CONROY DAVID F. FENSTER KAREN ST. JOHN LAWRENCE A. WHITE

ROYAL INSTITUTE OF TECHNOLOGY-SWEDEN IVARS NERETNIEKS

ROYCES ELECTRONICS INC ROYC.F HFNNINCISON

SALT LAKE CITY TRIBUNE IIIA WOOLT

SAN DIEGO GAS \& ELECTRIC COMPANY STEPHEN B. ALLMAN

SAN IUAN RECORD JOYCE MARTIN

SANDIA NATIONAL. LABORATORIES JOY BEMESDERFER SHARLA BERTRAM MARGARET S. CHU ROBERT M. CRANWELL JOE A. FERNANDEZ THOMAS O. HUNTER MARTIN A. MOLECKE SCOTT SINNOCK DR. DAVID TOMASKO LYNN D. TYLER WENDELL WEART

SAVANNAH RIVER LABORATORY PETER L. GRAY CAROL JANTZEN WILLIAM R. MCDONELL. DONALD ORTH
SCIENCE APPLICATIONS INTERNATIONAL CORP MARY LOU BROWN

JERRY J. COHEN

BARRY DIAL

JAMES E. HAMMELMAN

ROBERT R. JACKSON

DEAN C. KAUL

DAVID H. LESTER

PETER E. MCGRATH

JOHN E. MOSIER

ANTHONY MULLER

DOUGLAS A. OUTLAW

HOWARD PRATT

PATTY ROWAN

MICHAEL E. SPAETH

ROBERT T. STULA

T. WILLIAM THOMPSON

M. D. VOEGELE

SHIMIZU CONSTRUCTION COMPANY

LTD-IAPAN

TAKASHI ISHII

SIERRA CLUB-COLORADO OPEN SPACE

COUNCIL.

ROY YOUNG

SIERRA CLUB LEGAL DEFENSE FUND, INC BILL CURTISS

SIMECSOL CONSULTING ENGINEERS-FRANCE MATTHEW LEONARD

SKBF/KBS-SWEDEN

C. THEGERSTROM

SOCO TECHNOLÖGY INC TIO C. CIILN

SOKAOGON CHIPPEWA COMMUNITY ARLYN ACKLEY

SOUTH DAKOTA OFFICE OF ENERGY POLICY STEVEN M. WEGMAN

SOUTHERN CALIFORNIA EDISON CO JOHN LADESICH

SOUTHERN STATES ENERGY BOARD I. F. CLARK

SOUTHWEST RESEARCH AND INFORMATION CENTER DON HANCOCK

SPRINC CREEK RANCH DALTON RED BRANGUS

SPRINGVILLE CITY LIBRARY

SRI INTERNATIONAL DIGBY MACDONALD

ST \& E, INC. STANLEY M. KLAINER

STANFORD UNIVERSITY GEORGE A. PARKS IRWIIIN RE/NISOIN

STATE OF TEXAS-NUCLEAR WASTE PROGRAMS OFFICE GARY RASP

STATE UNIVERSITY OF NEW YORK AT CORTLAND

IAMES E. BUGH

STATE UNIVERSITY OF NEW YORK AT STONY BROOK S. REAVEN

STONE \& WEBSTER ENGINEERING CORP NANCY E. PEARSON ARLENE C. PORT EVERETT M. WASHER

STUDIO GEOLOGICO FOMAR-ITALY A. MARTORANA

STUDSVIK ENERGITEKNIK AB-SWEDEN AKE HULTGREN ROLF SJOBLOM

SYRACUSE UNIVERSITY WALTER MEYER
TAYLOR INSTRUMENT

PETER ALEXANDER

TECHNICA INC

AHAMAD SHAFACHI

TECHNICAL INFORMATION PROJECT DONALD PAY

TEXAS A \& M UNIVERSITY STEVE MURDOCK JAMES E. RUSSELL

TEXAS BUREAU OF ECONOMIC GEOLOGY WILLIAM L. FISHER

TEXAS DEPT OF AGRICUITURE GARY KEITH

TEXAS DEPT OF HEALTH DAVID K. LACKER

TEXAS DEPT OF WATER RESOURCES T. KNOWLES

TEXAS GOVERNORS OFFICE STEVE FRISHMAN

TEXAS TECH UNIVERSITY DAVID PROCTOR

THE ANALYTIC SCIENCES CORP JOHN W. BARTLETT CHARLES M. KOPLIK

THE BENHAM GROUP KEN SENOUR

THE DAILY SENTINEL JIM SULLIVAN

THE FARTH TECHNOLOGY CORP FRED A. DONATH (2) JOSEPH G. GIBSON FIA VITAR MATT WERNER KENNETH L. WILSON

THE RADIOACTIVE EXCHANGE EDWARD L. HELMINSKI

THE SEATTLE TIMES ELOUISE SCHUMACHER

TIOGA COUNTY PLANNING BOARD THOMAS A, COOKINCHAM

TULIA NUCLEAR WASTE INFORMATION OFFICE NADINE COX

U.S. BUREAU OF LAND MANAGEMENT GREGORY F. THAYN

U.S. BUREAU OF RECLAMATION IOHN BROWN REGE LEACH

U.S. DEPT OF COMMERCE PETER A. RONA

U.S. DEPT OF ENERGY

C. R. COOLEY (2) R. COOPERSTEIN NNEAL UUINCAIN JIM FIORE ROGER MAYES CARL NEWTON IANIE SHAHEEN

U.S. DEPT OF ENERGY-ALBUQUERQUE OPERATIONS OFFICE PUBLIC READING ROOM

U.S. DEPT OF ENERGY-CHICAGO OPERATIONS OFFICE

BARRETT R. FRITZ

VICKI PROUTY

PUBLIC READINC ROOM

R. SELBY

U.S. DEPT OF ENERGY-IDAHO OPERATIONS OFFICE

JAMES F. LEONARD

PUBLIC READINC ROOM 
U.S. DEPT OF ENERGY-NEVADA OPERATIONS OFFICE PUBLIC READING ROOM

U.S. DEPT OF ENERGY-OAK'RIDGE OPERATIONS OFFICE PUBLIC READING ROOM

U.S. DEPT OF ENERGY-OFFICE OF CIVILIAN

RADIOACTIVE WASTE

D. H. ALEXANDER (2)

R. J. BLANEY

I. C. BRESEE

J. F. DALY

M. W. FREI

B. G. GALE

R. W. GALE

N. DEL GOBBO

THOMAS ISAACS

S. H. KALE

C. E. KAY

f. P. KNIGHT

GERALD PARKER

B. C. RUSCHE

RALPH STEIN

U.S. DEPT OF ENERGY-OFFICE OF ENERGY

RESEARCH

FRANK J. WOBBER

U.S. DEPT OF ENERGY-OSTI (250)

U.S. DEPT OF ENERCY-RICHLAND OPERATIONS

OFFICE

D. H. DAHLEM

PUBLIC READING ROOM

U.S. DEPT OF ENERGY-SALT REPOSITORY

PROJECT OFFICE

RAM B. LAHOTI

K. K. WU

U.S. DEPT OF ENERCY-SAN FRANCISCO

OPERATIONS OFFICE

PUBLIC READINC ROOM

U.S. DEPT OF ENERGY-SAVANNAH RIVER

OPERATIONS OFFICE

PUBLIC READING ROOM

U.S. DEPT OF ENERGY-WASTE ISOLATION

PILOT PLANT

ARLEN HUNT

U.S. DEPT OF THE INTERIOR

MATTHEW JAMES DEMARCO

F. L. DOYLE

U.S. ENVIRONMENTAL PROTECTION AGENCY JAMES NEIHEISEL

U.S. ENVIRONMENTAL PROTECTION AGENCY -

DENVER REGION VIII

'PHIL INY'BERG

U.S. ENVIRONMENTAL PROTECTION AGENCY-

REGION II

EPA L.IBRARY

U.S. GEOLOGICAL SURVEY

DARWIN KNOCHENMUS

JACOB RUBIN

U.S. GEOLOGICAL SURVEY-DENVER JESS M. CLEVELAND

UIS: GEOLOGICAL SURVEY-NUCLEAR WASTE

PROCRAM, WATER RESOURCES DIVISION GEORGE A. DINWIDDIE

U.S. GEOLOGICAL SURVEY-RESTON

NEIL PLUMMER

DAVID B. STEWART

NEWELL J. TRASK, JR.

U.S. GEOLOGICAI. SURVEY-WATER RESOURCES

DIVISION

PETER B. DAVIES

U.S. GEOLOGICAL SURVEY NATIONAL CENTER IIM ROLLO
U.S. NUCLEAR RECULATORY COMMISSION

KIEN C. CHANG

EILEEN CHEN

F. ROBERT COOK

DOCKET CONTROL CENT

PHILIP S. IUSTUS

JOHN C. MCKINLEY

TIN MO

NRC LIBRARY

EDWARD OCONNELL

CHARLES H. PETERSON

JACOB PHILIP

JOHN TRAPP

TILAK R. VERMA

JOHN C. VOCLEWEDE

U.S. SENATE

CARL LEVIN

BILL SARPALIUS

UNDERGROUND SPACE

DONNA AHRENS

UNITED KINGDOM DEPT OF THE

ENVIRONMENT

F. S. FEATES

UNITED NUCLEAR CORPORATION TECHNICAL

SERVICES INC CHARLES A. JONES

UNIVERSIIEE UU QUEBEC EN ABITIBI-

TEMISCAMINGUE

MICHEL AUBERTIN

UNIVERSITY COLLEGE LONDON

B. K. ATKINSON

UNIVERSITY OF ALBERTA-CANADA

F. W. SCHWARTZ

UNIVERSITY OF ARIZONA

JAAK DAEMEN

I. W. FARMER

AMITAVA GHOSH

JAMES G. MCCRAY

ROY G. POST

UNIVERSITY OF BRITISH COLUMBIA-CANADA R. ALLAN FREEZE

UNIVERSITY OF CALIFORNIA AT BERKELEY TODD LAPORTE

UNIVERSITY OF CALIFORNIA AT LOS ANCELES D. OKRENT

UNIVERSITY OF ILLINOIS AT URBANA-

CHAMPAIGN

ALBERT J. MACHIELS

MAGDI RAGHEB

UNIVERSITY OF LOWELL

IAMES R. SHEFF

UNIVERSIIY OF MARYLAND AMERICAN NUCLEAR SOCIETY

UNIVERSITY OF MASSACHUSETTS GEORGE MCGILL

UNIVERSITY OF MISSOURI AT COLUMBIA W. D. KELLER

UNIVERSITY OF MISSOURI AT KANSAS CITY SYED E. HASAN

UNIVERSITY OF MISSOURI AT ROLLA

ALLEN W. HATHIEWAY

ARVIND.KUMAR

UNIVERSITY OF NEW MEXICO

DUUULLAS G. BRUUKKINS

RODNEY C. EWING

UNIVERSITY OF OKLAHOMA DANIEL T. BOATRIGHT

UNIVERSITY OF OTTAWA-CANADA TUNCER OREN

UNIVERSITY OF PITTSBURGH B. L. COHEN

UNIVERSITY OF SOUTHERN MISSISSIPPI CHARLES R. BREENT
UNIVERSITY OF TEXAS AT AUSTIN BUREAU OF ECONOMIC GEOLOGY CAROLYN E. CONDON

UNIVERSITY OF TEXAS AT SAN ANTONIO DONALD R. LEWIS

UNIVERSITY OF TOLEDO DON STIERMAN '

UNIVERSITY OF UTAH STEVEN J. MANNING MARRIOTT LIBRARY JAMES A. PROCARIONE GARY M. SANDQUIST

UNIVERSITY OF UTAH RESEARCH INSTITUTE LIBRARY

UNIVERSITY OF WASHINGTON DAVID BODANSKY M. A. ROBKIN

UNIVERSITY OF WATERLOO F. SYKES

UTAH DEPT OF HEALTH LARRY F. ANDERSON

UTAH DEPT OF TRANSPORTATION DAVID LLOYD

UTAH DIVISION OF PARKS \& RECREATION GORDON W. TOPHAM

UTAH ENERCY OFFICE ROD MILLAR

UTAH HIGH LEVEL NUCLEAR WASTE OFFICE RUTH ANN STOREY

UTAH SOUTHEASTERN DISTRICT HEALTH DEPT ROBERT L. FURLOW

UTAH STATE GEOLOGIC TASK FORCE DAVID D. TILLSON

VANDERBILT UNIVERSITY FRANK L. PARKER

VEGA NUCLEAR WASTE INFORMATION OFFICE EFFIE HARLE

VERMONT HOUSE OF REPRESENTATIVES RALPH C. WRIGHT

VERMONT STATE NUCLEAR ADVISORY PANEL VIRGINIA CALLAN

VIRGINIA DEPT OF HEALTH ROBER'T' C. WICKLINE

VIRGINIA POWER COMPANY B. H. WAKEMAN

WASHINGTON HOUSE OF REPRESENTATIVES RAY ISAACSON

WASHINGTON STATE DEPT OF ECOLOGY TERRY HUSSEMAN

WATTLAB BOB E. WATT

WELL SITE GEOLOGICAL SERVICES WAYNE S. GREB

WEST VALLEY NUCLEAR SERVICES COMPANY INC LARRY R. EISENSTATT

WESTERN MICHICAN UNIVERSITY RICHARD PASSERO W. THOMAS STRAW

WESTERN STATE COLLEGE FRED R. PECK

WESTINCHOUSE ELECTRIC CORP GEORGE V. B. HALL YOZO ISOGAI WIPP PROJECT

WESTINCHOUSE ELECTRIC CORP -NUCLEAR

WASTE DEPARTMENT

C. R. BOLMGREN

WESTINGHOUSE HANFORD COMPANY ROBERT FINZIGER

WESTINGHOUSE IDAHO NUCLEAR COMPANY INC

NATHAN A. CHIPMAN 
WESTON GEOPHYSICAL CORP CHARLENE SULLIVAN

WEYER CORP INC K. U. WFYFR

WILLIAMS AND ASSOCIATES INC GERRY WINTER

WISCONSIN DEPT OF NATURAL-RESOUURCES DUWAYNE F. GEBKEN
WISCONSIN DIVISION OF.STATE ENERGY ROBERT HALSTEAD

WISCONSIN STATE SENATE JOSEPH STROHL

WISCONSIN WATER RESOURCES MANAGEMENT SALLY J. KEFER

WITHERSPOON, AIKEN AND LANCLEY SID HAM
WOODWARD-CLYDE CONSULTANTS

TERRY A. GRANT

ASHOK PATWARDHAN

WESTERN REGION LIBRARY

YALE UNIVËRSITY

G. R. HOLEMAN 


\section{COMMENT SHEET}

To the User: The purpose of this sheet is to give you the opportunity to provide feedback to DOE on the usefulness of this report and to critique it. Please submit your comments below and return the sheet.

Comments

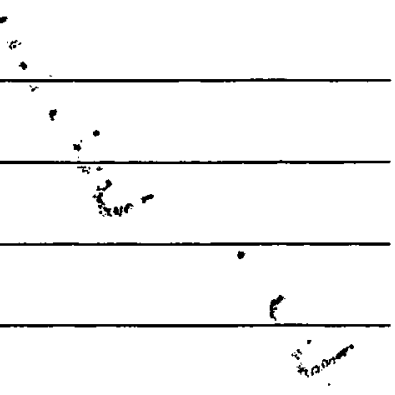

(Use additional sheet if necessary.)

Name

Date

Organization

Street

City Slate

Zip Cude or Country

Telephone Number ( ) 


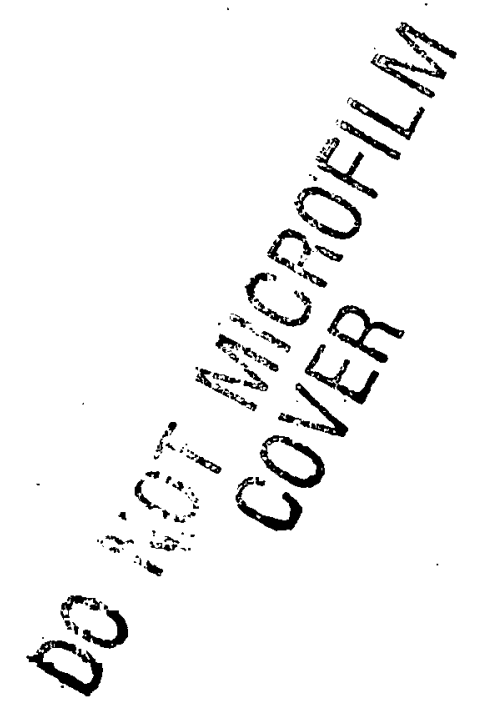

JEFFERSON O. NEFF, MANAGER

SALT REPOSITORY PROIIECT OFFISF

U.S. DEPARTMENT OF ENERGY

110 N. 25-MILE AVENUE

HEREFORD, TEXAS 79045 


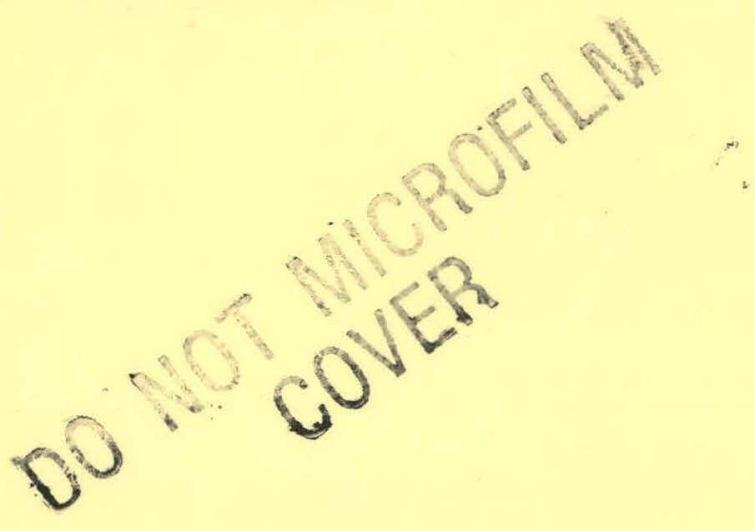

